Golden Gate University School of Law GGU Law Digital Commons

2016

Substantive Equality and Sexual Orientation: Twenty Years of Gay and Lesbian Rights Adjudication Under the South African Constitution

Eric C. Christiansen

Golden Gate University School of Law, echristiansen@ggu.edu

Follow this and additional works at: http://digitalcommons.law.ggu.edu/pubs

Part of the Civil Law Commons, Comparative and Foreign Law Commons, and the Sexuality and the Law Commons

Recommended Citation

49 Cornell Int'l. L.J. 565 (2016).

This Article is brought to you for free and open access by the Faculty Scholarship at GGU Law Digital Commons. It has been accepted for inclusion in Publications by an authorized administrator of GGU Law Digital Commons. For more information, please contact jfischer@ggu.edu. 


\title{
Substantive Equality and Sexual Orientation: Twenty Years of Gay and Lesbian Rights Adjudication Under the South African Constitution
}

\author{
Eric C. Christiansen $\dagger$
}

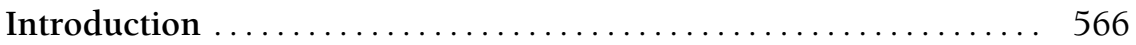

I. The Path to Constitutional Sexual Orientation

Protections ................................ 568

A. The Rise of Post-Apartheid Constitutionalism in South Africa ....................................... 568

1. Negotiating a Democratic Constitution for PostApartheid South Africa....................... 568

2. Sexual Orientation and the Post-Apartheid Constitutions ............................. 572

a. Interim Constitution Drafting Period ......... 574

b. Final Constitution Drafting Period ........... 576

i. Technical Committee Support ............ 577

ii. Gay and Lesbian Advocacy in the Final Drafting Period ..................... 579

iii. Organized Opposition to Sexual Orientation Protections ........................ 580

iv. Sexual Orientation in the Public Participation Programme .............. 581

v. Sexual Orientation is Included in the Final Constitution ....................... 584

B. Explaining Gay Equality in the Constitutional Drafting Process ................................... 585

1. The Role of History and Timing................ 585

2. Ideology and Non-Racialism ................. 586

3. Constrained Drafting Process ................. 587

$\dagger$ Professor of Law and Faculty Chair, Golden Gate University School of Law, San Francisco, California; J.D., New York University School of Law, 2001; M.A., University of Chicago, 1995; B.A., University of Notre Dame, 1992; 2016-17 Senior Fulbright Scholar; former Foreign Law Clerk, Chief Justice Arthur Chaskalson, Constitutional Court of the Republic of South Africa; echristiansen@ggu.edu. I wish to thank several colleagues for their comments, insights, and support, especially Michele Benedetto Neitz, Bill Gallagher, Kathleen Morris, Stephanie Hennette-Vauchez, Penelope Andrews, and Rachel Van Cleave. Additionally, two of my research assistants are owed particular thanks for their assistance with this Article: Jason Mustard and Olivia Porter.

49 Cornell Int'L L.J. 565 (2016) 
II. Gay and Lesbian Rights at the South African Constitutional Court ......................... 588

A. Decriminalization in the NCGLE Sodomy Case ........ 588

B. Getting to the Altar: Family and Relationship Recognition ............................. 591

C. Marriage Equality at the Constitutional Court ....... 594

III. A South African Gay Rights Jurisprudence ............. 597

A. Summarizing Twenty Years of Constitutional Adjudication ................................ 597

1. Impactful Engagement ...................... 597

2. Contextual Assessment ........................ 599

3. Transformative Values ......................... 600

B. The Inadequacy of Constitutional Law Protections ..... 601

1. Danger and Disfavor....................... 602

2. Social Change and the Courts................. 604

IV. Lessons from the South African Experience............. 605

A. Lessons for Progressive Constitutional Drafting ....... 605

B. Lessons for Advancement of Constitutional Equality ... 608

1. Guiding Official State Action ................... 608

2. Leveraging Legitimacy........................ 609

3. Inspiring Future Claims .................... 610

C. Lessons for Comparative Equality and

Constitutionalism ............................. 612

Conclusion ...................................... 614

\section{Introduction}

On the day Nelson Mandela was elected President of the newly democratic Republic of South Africa, a new constitution ended the most egregious system of legal discrimination in the world: South African apartheid. This past year marks the twentieth anniversary of South Africa's transition to democracy and the inauguration of the 1996 Constitution. There has been abundant exposure to South African constitutional law over the last two decades because of admiration for its Bill of Rights, respect for the South African Constitutional Court, and fascination with the nation's compelling history as a human rights state born out of radical inequality.

Scholars have paid particular attention to South Africa's equality provisions because of the country's unique history. Among the exceptional elements of the South African Equality Clause is its novel and progressive inclusion of anti-discrimination protections for lesbians and gay men. ${ }^{1}$

1. It is worth noting that this Article intentionally uses the terminology "gays and lesbians" and "gay rights" rather than the more comprehensive term LGBTI (lesbian, gay, bisexual, transgender, and intersex) persons and rights. The focus of this Article on homosexuality to the exclusion of other sexual orientations (like bisexuality) or affiliated categories of discrimination (like gender identity discrimination), except where those issues intersect with discrimination against gays and lesbians, is neither because the discrimination and prejudice is any less severe nor the issues less compelling. Nor is the narrower focus because the South African Constitution does not prohibit discrimina- 
The prohibition of discrimination based on sexual orientation is particularly important because it occurred-for the first time in any national constitution-as a result of the closely-watched drafting of South Africa's historic "human rights" constitution. ${ }^{2}$ The South African Constitution advanced the hopes of international gay rights advocates and set a benchmark for future constitutional drafters. The drafters' generous interpretation of contemporary human rights developments and their reformist reading of international law precedents resulted in trail-blazing protections. These advancements were supported by the moral authority of the South African victory over apartheid and buttressed by the progressive credentials of the activists who participated in (or publically affirmed) the constitutional result. ${ }^{3}$

The promise of the Constitution's equality protections was realized in a sequence of highly visible legal victories for gays and lesbians. Over the last two decades, the Constitutional Court of South Africa decriminalized same-sex sexual activity, required equal treatment of same-sex life partners in immigration and government benefits law, and affirmed the fundamental validity of same-sex relationships, including recognition of full marriage equality. The Court's opinions expressly affirmed the dignity and equality of gays and lesbians in an unbroken series of unanimous, pro-gay decisions. The rulings decisively opposed discrimination based on sexual orientation and established the present standards for a substantial portion of the Constitutional Court's broader equality jurisprudence.

Indeed, the South African gay rights jurisprudence exceeds the broadest advancements of legal protections anywhere else in the world and contrasts starkly with the appalling road taken by many countries, including nearly every other sub-Saharan African country. ${ }^{4}$ However, court rulings tell only a part of the story. Although twenty years have passed since

tion on those additional bases; there is direct textual support that it does. However, the Constitutional Court has yet to decide a significant case applying the Equality Clause on those more expanded bases and, indeed, the Court has made no substantive statements about such discrimination in its first two decades. I do not wish to contribute to the further invisibility of bisexual, transgender, and intersex persons in the literature, but for purposes of this particular Article, the absent elements of the Court's jurisprudence leave little to comment upon-other than the Court's silence to date. Further sociological and legal research is needed to examine the impact and consequence of this absence.

2. Makua wa Mutua, Hope and Despair for a New South Africa: The Limits of Rights Discourse, 10 HaRv. Hum. RTS. J. 63, 65 (1997) ("[T]he first deliberate and calculated effort in history to craft a human rights state-a polity that is primarily animated by human rights norms.").

3. See Tom Lodge, The Interplay of Non-Violent and Violent Action in the Movement against Apartheid in South Africa, 1983-1994, in Civil Resistance And Power Politics: The Experience of Non-Violent Action from Gandhi to the Present 213, 227 (Adam Roberts \& Timothy Garton Ash eds., 2011).

4. See Kim Yi Dionne, Should we call Africa homophobic?, Wash. Post (July 10, 2015), https://www.washingtonpost.com/blogs/monkey-cage/wp/2015/07/10/why-imnot-calling-africa-homophobic-anymore/. See generally LAW LibraRY OF CONG., Glob. Legal Research Ctr., Laws on Homosexuality in Africa (2014), http://www.loc.gov/ law/help/criminal-laws-on-homosexuality/homosexuality-laws-in-african-nations.pdf (summarizing the treatment of homosexuality in the criminal laws of forty-nine African nations). 
the Equality Clause prohibited sexual orientation discrimination, its practical effect has been markedly inadequate to achieve the safety and social equality of LGBT persons in South Africa. In sharp contrast to the Constitution's expansive textual protections and progressive jurisprudence, South African gays and lesbians, particularly in poorer communities, routinely experience condemnation, discrimination, and homophobic violence. Hence, the Equality Clause is a symbol of both the progressive aims of the post-apartheid constitution and the appalling gulf between those aspirations and reality.

Examining the historical achievements and failures of the Constitution's sexual orientation protections highlights larger lessons from the last twenty years of constitutionalism in South Africa. In this Article, I use the drafting history, Constitutional Court adjudication, and the practical insufficiencies of the Constitution's inclusion of sexual orientation-based protections to highlight three categories of insights. These lessons include an encouraging insight regarding the inclusion of novel and progressive elements when drafting modern constitutions; some modest claims about the capacity of courts to combat inequality based on sexual orientation despite the limitations of purely legal victories; and a hopeful affirmation of the value of even unrealized constitutional aspirations for the fields of comparative constitutionalism and gay and lesbian equality.

\section{The Path to Constitutional Sexual Orientation Protections}

\section{A. The Rise of Post-Apartheid Constitutionalism in South Africa}

In the early 1990s South Africa achieved a goal considered impossible throughout long decades of oppressive, state-sponsored racism: a relatively nonviolent transition from "racial autocracy to a nonracial democracy by means of a negotiated transition, the progressive implementation of democracy, and respect for fundamental human rights." ${ }^{5}$ The antithesis of apartheid, equality and human dignity were core values in the democratic transition and were therefore prominently placed and repeatedly affirmed in both of South Africa's transitional constitutions.

\section{Negotiating a Democratic Constitution for Post-Apartheid South Africa}

The initial dispute between the dominant political parties at the 1991 Convention for a Democratic South Africa ("CODESA") focused on the process for drafting the constitution. ${ }^{6}$ Was the purpose of CODESA to draft a minimal constitutional outline that would merely facilitate the democratic election of a popularly-elected body empowered to draft a full constitution?

5. Albie Sachs, Constitutional Developments in South Africa, 28 N.Y.U. J. INT'L L. \& Pol. 695, 695 (1996). See generally A Brief History of the African National Congress, African Nat'l Cong., http://www.anc.org.za/content/brief-history-anc (last visited Sept. 20, 2016) (detailing the history of the African National Congress in South Africa since the mid-1800s).

6. Allister Sparks, Tomorrow Is Another Country: The Inside Story of South Africa's Road to Change 133 (1995). 
Or, were the party-appointed CODESA delegates empowered to negotiate all the terms of the nascent constitution? The popular, newly unbanned African National Congress ("ANC") wanted to constrain CODESA's authority as much as possible so that the new constitution would be drafted by a newly elected (and sure-to-be ANC-dominated) Parliament. ${ }^{7}$ The incumbent, white-minority National Party ("NP") wanted CODESA to write an entire constitution, leveraging their suddenly-diminishing power to protect the white minority through codification of group rights, protection from prosecution for apartheid-era actions, and clauses preserving the economic status quo. ${ }^{8}$ These diametrically opposed visions of the CODESA process and the atmosphere of suspicion surrounding it were substantial enough that CODESA discussions collapsed in mid-1992 without producing a new constitution. ${ }^{9}$ Significant concessions by both parties permitted the drafters to resume work approximately a year later through a renamed drafting conference called the Multi-Party Negotiating Process ("MPNP"). ${ }^{10}$ The compromise, a two-part solution to the over-arching procedural problem, included a two-stage drafting process and the formation of a constitutional court that would have authority to enforce the parties' negotiated agreement. ${ }^{11}$

The first of the two negotiated stages of the transition involved drafting a modest, temporary constitution (the "Interim Constitution") and holding South Africa's first democratic elections. ${ }^{12}$ The freshly elected members of the Interim Constitution's new Parliament would then select a new president. In the second stage of the transition, the task of crafting the full, final constitution (the "1996 Constitution") ${ }^{13}$ was assigned to the newly elected Parliament and Senate in their ancillary role as the Constitutional Assembly. ${ }^{14}$

Two safeguards linked the two stages of this carefully-crafted process. First, a set of thirty-four binding constitutional principles ("the Thirty-Four

7. Patti Waldmeir, Anatomy of a Miracle: The End of Apartheid and the Birth of THE New South Africa 202 (1997) (providing general histories of the political transformation of South Africa at the end of the apartheid era).

8. Id. See generally SPARKs, supra note 6 (detailing the negotiating process that led to majority rule).

9. See Dawid van Wyk, Introduction to the South African Constitution, in Rights AND Constitutionalism, The New South African Legal Order 131, 139 (Dawid van Wyk et al. eds., 1994).

10. Id. at 140 .

11. S. Afr. (Interim) Const., 1993, ch. 7, § 98(1). Nelson Mandela originally proposed the two-stage drafting process one year prior to the start of CODESA. President de Klerk tacitly approved it at CODESA's inaugural session, and it was formalized over the course of CODESA. See WALDMEIR, supra note 7, at 194-95.

12. See Sparks, supra note 6, at 134-35.

13. S. Afr. Const., 1996. It is, of course, a bit of a misnomer to refer to the 1996 Constitution as the final constitution. The "final" Constitution has been amended seventeen times since its completion in December 1996, although none are directly relevant to this Article. For a complete list of amendments to the Constitution, see Amendments to the Constitution, S. AFr. Gov'T, www.gov.za/documents/constitution-amendments (last visited Mar. 31, 2015).

14. S. Afr. (Interim) Const., 1993, sched. 4; Hassen Ebrahim, The Soul of A Nation: Constitution-making in South Africa 177, 180 (1998). 
Principles") was agreed upon by the MPNP parties and attached to the Interim Constitution as Schedule $4 .{ }^{15}$ The Thirty-Four principles were intended to guide and constrain the choices made by the later drafters of the final constitution. Second, a constitutional court was created under the Interim Constitution to "certify" that any subsequent constitution conformed to the negotiated agreement preserved in the Thirty-Four Principles. ${ }^{16}$

This initial drafting period, including CODESA and the MPNP, lasted nearly two years. The Interim Constitution, with its thoroughly negotiated Thirty-Four Principles, was agreed to on November 17, 1993. ${ }^{17}$ The provisions of the Interim Constitution -with its Bill of Rights including protections with regard to sexual orientation-came into effect on the first day of South Africa's first multiracial elections, April 26, 1994.18 The results of the election were particularly important given the elected parliamentary members' additional role as drafters of the Constitution that would replace the Interim Constitution. After three days of voting, South Africa's first democratic elections gave the ANC $62.7 \%$ of the National Assembly and made Nelson Mandela the President of the Republic of South Africa. ${ }^{19}$

The elected members of the National Assembly and the Senate, in their additional role as the Constitutional Assembly, formally began working on the final Constitution in May 1994. ${ }^{20}$ Under the terms of the Interim Constitution, the Constitutional Assembly had a mandated two-year timeframe to complete this task. ${ }^{21}$ The drafting work was conducted primarily in small, confidential Theme Committees rather than in large, public sessions. ${ }^{22}$ The Committees held hearings; analyzed submissions from political parties, private organizations, and citizens; and identified areas of agreement and disagreement. ${ }^{23}$ The Theme Committees regularly reported findings and made recommendations to the Constitutional Assembly as a whole, but the core of the decision-making process occurred at the Consti-

15. S. Afr. (Interim) Const., 1993, sched. 4.

16. Id. at ch. 7; Albie Sachs, South Africa's Unconstitutional Constitution, 41 ST. Louis U. L.J. 1249, 1255 (1997).

17. Lourens du Plessis \& Hugh Corder, Understanding South Africa's Transitional Bill of Rights 2-17 (1994).

18. Andrew Reynolds, The Results, in Election '94 South Africa: The Campaign, Results and Future Prospects 182, 184-87 (Andrew Reynolds ed., 1994).

19. South Africa's democratic elections were held over several days beginning on April 26, 1994. Despite allegations of fraud and ballot tampering, the results (outside KwaZulu-Natal) conformed with expectations to a significant degree: the ANC received a strong but not overly dominant $62.7 \%$, the NP received a disappointing $20.4 \%$, the Zulunationalist Inkatha Freedom Party won the KwaZulu-Natal Province, and the extremist parties on both the left and right received only marginal percentages. Id. at 182-83.

20. Jeremy Sarkin, The Drafting of South Africa's Final Constitution from a HumanRights Perspective, 47 Ам. J. Comp. L. 67, 69 (1999).

21. S. Afr. (Interim) Const., 1993, ch. 5 , § 73.

22. Theme Committees were identified by number and had the following foci: (1) character of state, (2) structure of state, (3) relations between levels of government, (4) fundamental rights, (5) judiciary and legal systems, and (6) specialized structures. See Sarkin, supra note 20, at 70 n.23 (1999).

23. Id. at 70 . 
tutional Committee, the authoritative party-based negotiating body of the Constitutional Assembly. ${ }^{24}$

Additionally, the Constitutional Assembly launched an ambitious program to educate the public about the constitution and to engage South Africans in the drafting process: The Public Participation Programme. The Public Participation Programme "recognized the fundamental significance of a [c]onstitution in the lives of citizens" and ostensibly "sought to place public participation at the centre of the [c]onstitution-making process." 25 The Programme was meant to invite citizen involvement in the constitutional process and thereby to increase the constitution's popular legitimacy. 26 The Programme held in-person informational sessions, distributed booklets related to the process (and later, the proposed text), and facilitated the submission of public commentary about the constitution. ${ }^{27}$ Over the course of the Programme, the Constitutional Assembly received more than two million submissions from citizens and domestic groups. $^{28}$

24. The Constitutional Committee was comprised of members of the seven political parties represented in Parliament in proportion to the number of seats they held in the National Assembly: The African National Congress (252 seats in Parliament), the National Party (82 seats), the IFP (43 seats), the Democratic Party ( 7 seats), the Freedom Front (9 seats), the Pan African Congress (5 seats), and the African Christian Democratic Party (2 seats). See Reynolds, supra note 18, at 183.

25. Eric C. Christiansen, Ending the Apartheid of the Closet: Sexual Orientation in the South African Constitutional Process, 32 N.Y.U. J. InT'L L. \& PoL. 997, 1007 (2000) [hereinafter Christiansen, Ending the Apartheid of the Closet] (internal quotation marks and citation omitted); see also EBrahim, supra note 14, at 239-50 (detailing the successes of the Public Participation Programme in engaging the public).

26. As the media releases from the Constitutional Assembly described it: "The final submission was hand-delivered to the Constitutional Assembly at 11:30pm and at midnight the fax lines were still humming as the country's greatest ever public participation campaign came to a close [on February 20, 1996]." Constitutional Talk: Official Newsl. Const. Assembly (Constitutional Assembly, Rep. of S. Afr.), vol. 2, 1996 [hereinafter Constitutional Talk, vol. 2]. Participation in all aspects of the program exceeded expectations. See Constitutional Talk: Official Newsl. Const. Assembly (Constitutional Assembly, Rep. of S. Afr.), vol. 9, June 30, 1995 [hereinafter Constitutional Talk, vol. 9].

27. Sarkin, supra note 20 , at 72 .

28. Submissions in phase one totaled 1.8 million, and submissions in phase two totaled 250,000. See Constitutional Talk: Official Newsl. Const. Assembly (Constitutional Assembly, Rep. of S. Afr.), vol. 8, June 8, 1995 [hereinafter Constitutional Talk, vol. 8]. Additionally, over 80,000 people attended public meetings and constitutional education workshops sponsored by the Assembly throughout the country. ConstituTIONAL TALK, vol. 2, supra note 26 . While there were complaints that the program was not fully effective at reaching rural communities, informal settlements, women, and elderly citizens, a 1996 independent survey found that the media campaign had reached 18.5 million people, an impressive $73 \%$ of adult South Africans. The survey was conducted by the Community Agency for Social Equality. Constitutional Talk: OfFicial Newsl. Const. Assembly (Constitutional Assembly, Rep. of S. Afr.), vol. 3, Apr. 22, 1996. Over four million copies of a special thirty-two-page Constitutional Talk edition were produced in all eleven official languages. The publication contained the complete text of the draft Constitution, explanatory articles outlining the issues, and a series of graphics aimed at making the often complex constitutional issues accessible to ordinary South Africans. See Constitutional Talk: Official Newsl. Const. Assembly (Constitutional Assembly, Rep. of S. Afr.), vol. 1, Feb. 9, 1996 [hereinafter Constitutional Talk, vol. 1]. 
The Constitutional Assembly adopted the 1996 Constitution by an overwhelming majority: 80 of 90 Senators and 321 of 400 National Assembly members voted in favor of the proposed final text. ${ }^{29}$ This was significantly greater than the requisite two-thirds majority of the entire Constitutional Assembly. ${ }^{30}$ The proposed constitution, however, could not be signed by the President or come into force until the Constitutional Court "certified" it. ${ }^{31}$

As a result of the compromise that allowed South Africa's first democratic elections, the Interim Constitution's Thirty-Four Principles established "the fundamental guidelines, the prescribed boundaries, according to which and within which the [Constitutional Assembly] was obliged to perform its drafting function." 32 The Constitutional Court was required to declare that the proposed text complied with each of the Thirty-Four Principles annexed to the Interim Constitution. ${ }^{33}$ The expansiveness of the proposed Equality Clause text was one of the many elements challenged when the Certification Case came before the Constitutional Court. ${ }^{34}$ The Court rejected the challenge and the Equality Clause, which included the world's first express sexual orientation protections, remained in the 1996 Constitution. ${ }^{35}$

\section{Sexual Orientation and the Post-Apartheid Constitutions}

Broadly enforceable equality rights were a legal refutation of apartheid-era discrimination and a substantiation of ANC claims that postapartheid South Africa would be based on "non-racialism." As the end of apartheid approached, the formerly banned ANC had to codify its policies and protest statements into constitutional rights text. Hence, even before Mandela was released from prison or the ban on the ANC lifted, the 1989 ANC publication Constitutional Guidelines for a New South Africa asserted the need for a justiciable Bill of Rights in a post-apartheid South Africa: "The Constitution shall include a Bill of Rights based on the Freedom

29. Sarkin, supra note 20 , at 72 .

30. The Constitutional Assembly consisted of the four hundred newly elected members of the National Assembly and the ninety members of the Senate. ReP. OF S. Afr., Debates of the Constitutional Assembly, vol. 3, at 447-52, 524-25 (1996).

31. See S. Afr. (Interim) Const., 1993, ch. 5, § 71(2) ("The new constitutional text passed by the Constitutional Assembly, or any provision thereof, shall not be of any force and effect unless the Constitutional Court has certified that all the provisions of such text comply with the [Thirty-Four] Constitutional Principles ....."); Certification of the Constitution of the Republic of South Africa 1996 (4) SA 744 (CC) at 21 para. 32 (S. Afr.) ("It is necessary to underscore again that the basic certification exercise involves measuring the [final constitutional text] against the [Thirty-Four Principles]"); Certification of the Constitution of the Republic of South Africa 1996 (4) SA 744 (CC) at 12 para. 17 ("[C]ertification mean[t] a good deal more than merely checking off each individual provision of the [final text] against the several [Principles]").

32. Certification of the Constitution 1996 (4) SA 744 (CC) at 21 para. 32 (S. Afr.).

33. Id. at $1-3,8-13,18-21$ paras. $1-4,12-19,26-31$.

34. Id. at 61-64 paras. 96-103.

35. Ex parte Chairperson of the Constitutional Assembly: In re Certification of the Constitution of the Republic of South Africa, 19961996 (4) SA 744 (CC) (S. Afr.). 
Charter.[36] Such a Bill of Rights shall guarantee the fundamental human rights of all citizens ... and shall provide appropriate mechanisms for their enforcement." 37 The ANC produced more fully developed Bill of Rights drafts in $1990^{38}$ and again in 1992. ${ }^{39}$ To a significant degree, the civil and political rights outlined in those two ANC documents formed the ideological core of the Interim Constitution's Bill of Rights. Equality was a central element of all four documents.

Surprisingly, the ruling white-minority NP was, like the ANC, exploring options for a Bill of Rights prior to the formal end of apartheid. ${ }^{40}$ Not only were both of the main parties to the initial constitutional negotiations on similar timelines, but there were certain congruencies in the core elements of their proposals: protection of individual rights, limits on government power, and independent judicial oversight. ${ }^{41}$ Among the similarities were enforceable equality protections to ensure non-discriminatory state action. $^{42}$ By the time the Interim Constitution negotiations began, every major political party agreed that the final document would include a Bill of Rights with a substantial Equality Clause. ${ }^{43}$

36. Adopted by the 3,000-delegate Congress of the People on June 26, 1955, the ANC-authored Freedom Charter was the political manifesto of the anti-apartheid movement. In addition to the core tenet of multi-racialism, the document also emphasized redistribution of wealth, land ownership by those who work it, equal protection of the law, and other social and economic rights. It was the ANC's primary statement of values throughout most of its history and has been retroactively labeled a proto-Bill of Rights. For full text of the Charter, see The Freedom Charter, 21 Colum. Hum. RTs. L. Rev. 249, 249 (1989).

37. Constitutional Guidelines for a Democratic South Africa (1989), reprinted in 21 Colum. Hum. Rts. L. Rev. 235, 237 (1989). The Guidelines were the subject of extensive review and critique in South Africa. Albie Sachs, A Bill of Rights for South Africa: Areas of Agreement and Disagreement, 21 Colum. Hum. Ris. L. Rev. 13, 17 (1990) ("Indeed, so many bodies have taken up, analysed, and criticised the Guidelines that they have ceased to be simply an ANC document; instead they have become a working text for the entire anti-apartheid movement.").

38. See Constitutional Comm., African National Congress: A Bill of Rights for a Democratic South Africa-Working Draft for Consultation (1990), reprinted in 18 Soc. Just. 49, 49 (1991).

39. See Constitutional Comm., ANC Draft Bill of Rights: A Preliminary Revised Text (1992), reprinted in Albie Sachs, Advancing Human Rights In South Africa 215 (1992) [hereinafter 1992 ANC Draft Bill of Rights].

40. See S. African Law Comm'n, Working Paper No. 25, Project 58: Group and Human Rights (1989), reprinted in The South African Law Commission Bill of Rights, 21 Colum. Hum. Rts. L. Rev. 241, 241 (1990) [hereinafter Working Paper No. 25]; Lynn Berat, A New South Africa?: Prospects for an Africanist Bill of Rights and a Transformed Judiciary, 13 Loy. L.A. INT'L \& Comp. L.J. 467, 468 (1991).

41. Christiansen, Ending the Apartheid of the Closet, supra note 25, at 1014.

42. Edwin Cameron, Sexual Orientation and the Constitution: A Test Case for Human Rights, 110 S. Afr. L.J. 450, 450-51 (1993) [hereinafter Cameron, Sexual Orientation and the Constitution] (noting these shared characteristics).

43. See generally Du Plessis \& CORDER, supra note 17. This book's authors were the primary drafters of the interim Bill of Rights. See also Letter from Albie Sachs, Justice, Constitutional Court of South Africa, to Author (Jan. 7, 2000) (on file with author) [hereinafter Letter from Albie Sachs]. 


\section{a. Interim Constitution Drafting Period}

Gay and lesbian advocacy groups, which had worked to include sexual orientation protections in the early Bill of Rights proposals, continued their education and lobbying campaigns during the Interim Constitution drafting period. The success of the work of gay community activists was evident at the May 1992 ANC National Conference. Sexual orientation was mentioned twice in the party's formal policy guidelines. ${ }^{44}$ It became official ANC policy that "the right not to be discriminated against or subjected to harassment because of sexual orientation" would be included in any new constitution's bill of rights. ${ }^{45}$ Additionally, under "basic principles" related to social welfare policies, the document stated a goal of "full employment with a rising standard of living and quality of social and working life for all South Africans, regardless of race, sex, class, religion, creed, sexual orientation[,] and physical or mental disability." 46 Notably, this proposal's list of prohibited grounds for discrimination is very similar to the prohibited grounds in the Interim Constitution's Equality Clause, further highlighting the value of early lobbying efforts. ${ }^{47}$

Once the failed CODESA project was resurrected at the MPNP, the various political parties made their policies more explicit. The NP's Charter of Fundamental Rights, adopted as government policy in 1992 (and representing the NP's Bill of Rights proposal for the Interim Constitution), prohibited anti-gay discrimination by declaring that sexual orientation fell within the "other natural characteristics" against which discrimination was forbidden in its proposed non-discrimination clause. ${ }^{48}$ The ANC explicitly included "sexual orientation" in their 1992 draft Bill of Rights. ${ }^{49}$ The

44. Christiansen, Ending the Apartheid of the Closet, supra note 25, at 1029.

45. Policy Documents, African National Congress, Ready to Govern: ANC Policy Guidelines for a Democratic South Africa as Adopted at the National Conference, African NAT'L ConG., \& B.5 [hereinafter Ready to Govern].

46. Id. \& L.1.

47. See S. Afr. (Interim) Const., 1993, ch. 3, § 8(2) (declaring that age, language, and culture are all included). As their work with the ANC began to yield results, gay and lesbian activists began lobbying other parties as well. In June 1991, the Organisation for Lesbian and Gay Action contacted ten political parties and questioned them about their policy regarding general Bill of Rights protections of individual rights and the specific inclusion of sexual orientation as a protected category. Only the Democratic Party responded affirmatively to the question of explicit protections for gays and lesbians: "The Bill of Rights will guarantee all persons irrespective of ... sexual preference ... the following fundamental rights . . . [including] [e]qual protection of the law . . .." See Derrick Fine \& Julia Nicol, The Lavender Lobby: Working for Lesbian and Gay Rights Within the Liberation Movement, in Defiant Desire 269, 273 (Mark Gevisser \& Edwin Cameron eds., 1995). The National Party and Labour Party committed only to general protections of individual rights, the Conservative Party stated a Bill of Rights was unnecessary because "the Ten Commandments serve as the best Bill of Rights and all rights are sufficiently enshrined therein," and six other parties neglected to respond. Id.

48. This language was proposed by the National Party on February 2, 1993. See Edwin Cameron, 'Unapprehended Felons': Gays and Lesbians and the Law in South Africa, in Defiant Desire, supra note 47, at 89, 94-95 [hereinafter Cameron, Unapprehended Felons].

49. "It shall be unlawful to discriminate on the grounds of gender, single parenthood, legitimacy of birth or sexual orientation." 1992 ANC DRAFT BILl OF Rights, 
Democratic Party submission, following the policy it had previously reported, expressly outlawed direct and indirect discrimination based on sexual orientation. ${ }^{50}$ Even the Inkatha Freedom Party, the dominant regional party from KwaZulu-Natal, expressly prohibited such discrimination in its proposal: "All citizens . . . have equal social dignity, shall be equal before the law[,] and shall share an equal right of access to political, social, and economic opportunities irrespective of . . . sexual orientation ...."51 Although other, less significant parties did not include sexual orientation protections in their Bill of Rights proposals, either explicit or implicit protections were favored by parties that would go on to win $95.2 \%$ of the vote in the 1994 elections set up under the Interim Constitution. ${ }^{52}$

The inclusion of some form of sexual orientation protections in the dominant parties' draft Bills of Rights marked a tremendous accomplishment, ${ }^{53}$ but it did not ensure inclusion of reference to sexual orientation in the Interim Constitution. By the time of the MPNP, it remained unclear within the Technical Committee for Fundamental Rights whether the Equality Clause would take the form of a provision prohibiting discrimination against specific, enumerated classes ("No discrimination on the basis of race, religion, sex, etc.") or a generic non-discrimination provision ("No

supra note 39, art. 7(2); see also Ready to Govern, supra note 45, §§ B.5, J.1 (listing among protected rights in the introduction to the Bill of Rights, "the right not to be discriminated against or subjected to harassment because of sexual orientation," and, in the education, training, and scientific developments section, affirming "all individuals should have access to lifelong education and training, irrespective of . . sexual orientation").

50. The Democratic Party proposal stated:

[Art.] 2.1 Every person shall have the right to equal treatment, and there shall consequently be no discrimination, whether direct or indirect.

[Art.] 2.2 Discrimination means unjustified differentiation. Differentiation on the grounds of race, ethnic origin, colour, gender, sexual orientation, age, disability, religion, creed[,] or conscience shall be presumed unjustified unless it is part of a rational programme intended to remedy substantial inequality.

Democratic Party, Freedom Under the Rule of Law: Advancing Liberty in the New South Africa: Democratic Party Draft Bill of Rights, May 1993, at 1 (1993).

51. Other protected classifications included sex, race, colour, language, traditions, creed, religion, political affiliation and belief, and social and personal status. See KwaZulu Legislative Assembly, Resolution: Constitution of the State of KwaZulu/Natal $\S 10(a)$ Equality (Dec. 1, 1992), quoted in Cameron, Unapprehended Felons, supra note 48 , at 96 .

52. In the 1994 elections, the ANC received $62.6 \%$ of the popular vote, the NP received $20.4 \%$, the IFP received $10.5 \%$, and the DP received $1.7 \%$. Combined, they contributed $95.9 \%$ of the members of the Constitutional Assembly (384 of 400 members). See Reynolds, supra note 18, at 183.

53. In an appeal to a 1993 sodomy conviction, $S$ v. H, then judge (now Constitution Court Justice) Ackermann, while upholding a conviction for private, consensual sex between men, lessened the imposed sentence. Citing the various drafts of the thenpending Interim Constitution, the judge identified a "broad consensus on eliminating discrimination against homosexuality and the likelihood that this will be entrenched in a new constitutional dispensation." Voris Johnson, Making Words on a Page Become Everyday Life: A Strategy to Help Gay Men and Lesbians Achieve Full Equality under South Africa's Constitution, 11 Emory Int'L L. Rev. 583, 620 (1997) (citing State v. H. 1995 (1) SA 120 (CPD) at 124 (S. Afr.)). 
discrimination."). ${ }^{54}$ In the end, party negotiators chose to include the full enumeration of prohibited bases of discrimination as submitted by the Technical Committee. ${ }^{55}$ Persons familiar with that decision state that it was motivated in part by the vulnerability of gays and lesbians under less explicit or unenumerated Equality Clause formulations. ${ }^{56}$ This decision, combined with the fact that the Technical Committee was producing an extensive Bill of Rights draft (rather than a minimalist one), heightened the importance of the earlier proposals of the parties; the already established areas of agreement became presumptive elements of the constitutional draft. The result was expansive and express equality protections in the Interim Constitution.

A historic, albeit potentially temporary, victory had been secured. However, threats to the newfound protections awaited in the more public, more strongly majoritarian final constitution drafting process.

\section{b. Final Constitution Drafting Period}

The path from inclusion in the Interim Constitution to retention in the final 1996 Constitution was fairly straightforward for most portions of the

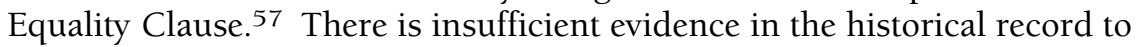
state definitively how vulnerable sexual orientation protections were. It is evident from Constitutional Assembly documents that although only a single party expressly opposed inclusion, the Assembly considered removing explicit references to sexual orientation. ${ }^{58}$ As late as October 1995, inclusion of sexual orientation as a protected class was still identified as a "contentious and outstanding issue" in the working draft of the final constitution. ${ }^{59}$ Indeed, a memorandum accompanying the November 22, 1995 working draft implied that sexual orientation protections were the sole controversial and undecided element of the Equality Clause. ${ }^{60}$

54. See Letter from Albie Sachs, supra note 43.

55. Christiansen, Ending the Apartheid of the Closet, supra note 25, at 1032.

56. See Letter from Albie Sachs, supra note 43. The Committee was also influenced by a written submission from the Equality Foundation, a pro-gay lobbying group. See Du Plessis \& Corder, supra note 17, at 142.

57. No categories were dropped between the Interim Constitution and the final Constitution; pregnancy, marital status, and birth were added. Compare S. Afr. (INTERIM) Const., 1993, ch. 3, § 8(2), with S. Afr. Const., 1996 § 9(3).

58. The most likely option would have been usage of language similar to the South African Law Commission phrase "natural characteristics" or the International Convention on Civil and Political Rights "or other status" language. See International Covenant on Civil and Political Rights art. 2, 26, Dec. 16, 1966, 999 U.N.T.S. 171 [hereinafter ICCPR]; Working PaPer No. 25, supra note 40.

59. See S. Liebenberg et al., Technical Committee of Theme Committee Four, Constitutional Assembly, Explanatory Memoranda on the Draft Bill of Rights of 9 October 1995: Overview of Method of Work 10-12 [hereinafter Explanatory Memoranda].

60. "However, some people say that it is wrong to include sexual orientation as one of the grounds for unfair discrimination. They argue that homosexuals should not be given this kind of protection in the new Constitution." Equality and Discrimination, Editorial Accompanying the Working Draft of the New Constitution, CONSTITUtion.org (Nov. 22, 1995), https://web.archive.org/web/19991108220224/http://www.constitution.org .za/edit/equal.html. 


\section{i. Technical Committee Support}

The Constitutional Assembly's Technical Committee of Theme Committee Four supported a broadly and expressly inclusive Equality Clause. ${ }^{61}$ Indeed, the committee discussed sexual orientation protections as a "universally accepted fundamental right" in its Explanatory Memoranda prepared for the Constitutional Committee. ${ }^{62}$ This implied that South Africa would be following the model of international law treaties or regional human rights courts. Inclusion of sexual orientation protections would be more publically acceptable and politically achievable if it were a codification of international human rights law rather than a South African innovation. ${ }^{63}$ Hence, the Technical Committee demonstrated the similarity between sexual orientation discrimination and other forms of proscribed discrimination in human rights documents: "The enumerated grounds of discrimination in international law relate to characteristics and choices which are an integral part of human personality and identity. They also include attributes of groups which are particularly vulnerable to discrimination, exclusion[,] and subordination." 64

The Technical Committee also very favorably interpreted the four cases decided prior to 1995 in which international human rights bodies had identified "sexual orientation" as a category for protection: ${ }^{65}$

The UN Human Rights Committee has interpreted sex as a prohibited ground of discrimination in articles 2(1) and article 26 of the [International Covenant on Civil and Political Rights (ICCPR)] to include sexual orientation. $\left.{ }^{66}\right]$ Thus the Committee has ruled that legislation criminalising all forms of sexual contact between consenting homosexual men to be in viola-

61. Theme Committee Four focused on fundamental rights in the final constitution. See Jeremy Sarkin, The Drafting of South Africa's Final Constitution from a Human-Rights Perspective, 47 Aм. J. Comp. L. 67, 70 n.23 (1999). Committee members are listed here: List of People that Made up the Constitutional Assembly, S. Afr. Hist. Online (Apr. 24, 2014), http://www.sahistory.org.za/list-people-made-constitutional-assembly.

62. See Explanatory Memoranda, supra note 59, at 7, § 4.2.3. This traces back to the Thirty-Four Principles of the Interim Constitution. Principle II stated that: "Everyone shall enjoy all universally accepted fundamental rights, freedoms and civil liberties ... provided for and protected by entrenched and justiciable provisions in the Constitution, which shall be drafted after having given due consideration to inter alia the fundamental rights contained in Chapter 3 of this [Interim] Constitution." S. AFr. (INTERIM) CONST., 1993, art. 2, sched. 4.

63. S. Afr. (Interim) Const., 1993, art. 2, sched. 4.

64. Explanatory Memoranda, supra note 59, at 10.

65. At the start of the constitutional drafting process, there had been only two such cases. See Norris v. Ireland, App. No. 10581/83, 13 Eur. Ct. H.R. 186 (1991); Dudgeon v. United Kingdom, App. No. 7525/76, 45 Eur. Ct. H.R. 20 (1981); AmNESTy INT'L, BREAKing the Silence: Human Rights Violations Based on Sexual Orientation 21-27, 29 , 32-41, 48-49 (1997).

66. ICCPR, supra note 58, art. 26. Article 26 states:

All persons are equal before the law and are entitled without any discrimination to the equal protection of the law. In this respect, the law shall prohibit any discrimination and guarantee to all persons equal and effective protection against discrimination on any ground such as race, colour, sex, language, religion, political or other opinion, national or social origin, property, birth[,] or other status. 
tion of the rights to privacy protected in article 17 of the Covenant read with the right to non-discrimination in the enjoyment of the rights protected in the Covenant.[ $\left.{ }^{67}\right]$ This is consistent with the case law of the European Court of Human Rights. ${ }^{68}$

Even today, twenty years later, it is overly optimistic to read international legal precedent as encompassing a blanket affirmation of gay and lesbian equal rights. While significant progress has been made, no formally adopted international human rights documents explicitly include protections of gays and lesbians or prohibit discrimination based on sexual orientation. ${ }^{69}$ Indeed, the first formal intergovernmental discussion of sexual orientation discrimination was not held until 2012. ${ }^{70}$

As further support for the inclusion of sexual orientation, the Technical Committee asserted:

$[\mathrm{M}]$ any countries and states have adopted anti-discrimination legislation which either expressly, or through interpretation, have included sexual orientation. Thus, for example, in the Canadian case of Haig $v$ Canada, $\left[{ }^{71}\right]$ it was held that sexual orientation should be treated as an analogous ground of discrimination and thus included within the scope of [section three] of the Canadian Human Rights Act. ${ }^{72}$

It must be acknowledged, that the use of the phrase "for example" was a bit disingenuous here. While it is true that anti-discrimination legislation that includes sexual orientation was reasonably common in developed Western countries by the mid-1990s, no country other than Canada had found that gays and lesbians were an implicitly protected category under a national constitution. ${ }^{73}$

Id.

67. U.N. Human Rights Comm., Toonen v. Australia, Communication No. 488/ 1992, U.N. Doc. CCPR/C/50/D/488/1992 (1994) [hereinafter Toonen]. Toonen asserted that the protection from discrimination based on "sex" in article 26 of the ICCPR was to be interpreted as including sexual orientation. Id. at 3. Advocates for gay rights had also argued that sexual orientation was covered under "other status" in article 26, and under the privacy provisions in article 17(1). ICCPR, supra note 58, art. 26.

68. Explanatory Memoranda, supra note 59, at 7, \& 4.2.3. The referenced European Court of Human Rights (ECHR) cases are Dudgeon, 45 Eur. Ct. H.R. at 63 (ruling that the Northern Ireland law criminalizing homosexual acts violated article 8 of the European Convention for Human Rights and Fundamental Freedoms, which guarantees "everyone the right to respect for private and family life, his home[,] and his correspondence"), Norris, 13 Eur. Ct. H.R. at 196 (ruling that Ireland's sodomy law violated article 8 of the European Convention), and Modinos v. Cyprus, App. No. 15070/89, 16 Eur. H.R. Rep. 485, 494 (1993) (applying Dudgeon and Norris holdings to Republic of Cyprus). See generally AmNeSTy InT'L, supra note 65.

69. See generally Michael O'Flaherty \& John Fisher, Sexual Orientation, Gender Identity and International Human Rights Law: Contextualising the Yogyakarta Principles, 8 Hum. Rts. L. Rev. 207, 217-48 (2008).

70. U.N. Office of the High Comm'r on Human Rights, Fact Sheet: International Human Rights law and Sexual Orientation \& Gender Identity (2012), http://www .ohchr.org/Documents/Issues/Discrimination/LGBT/FactSheets/unfe-11-UN_Fact_

Sheets_GenderIdentity_English.pdf.

71. Haig v. Canada, [1993] S.C.R. 995, 997-99 (Can.).

72. Explanatory Memoranda, supra note 59, at 7.

73. Christiansen, Ending the Apartheid of the Closet, supra note 25, at 1036. 
In fact, by the time the Technical Committee drafted its memorandum, only four favorable legal precedents related to the rights of gays and lesbians existed under international law. In Dudgeon v. United Kingdom, Norris v. Ireland, and Modinos v. Cyprus, ${ }^{74}$ the European Court of Human Rights ("ECHR") found that national sodomy laws were inconsistent with member states' obligations under Article Eight of the European Convention for Human Rights and Fundamental Freedoms. ${ }^{75}$ And, in Toonen v. Australia, the United Nations Human Rights Commission provided a similar ruling based on its classification of sexual orientation discrimination as a subset of sex discrimination. ${ }^{76}$ When the South African Constitution was being drafted those cases were very recent, atypical, and represented little with regard to precedent. ${ }^{77}$

Nevertheless, the Technical Committee was unambiguous in its final endorsement to the Constitutional Assembly: "[I]t is our strong recommendation that sexual orientation be included as a prohibited ground of discrimination in the [E]quality [C]lause."78

\section{ii. Gay and Lesbian Advocacy in the Final Drafting Period}

A newly formed coalition of activists and organizations under the name National Coalition for Gay and Lesbian Equality ("NCGLE") sponsored the gay and lesbian community's most evident efforts to influence the final text of the 1996 Constitution. ${ }^{79}$ NCGLE's primary focus was on

74. Norris v. Ireland, App. No. 10581/83, 13 Eur. Ct. H.R. 186 (1991); Dudgeon v. United Kingdom, App. No. 7525/76, 45 Eur. Ct. H.R. 20 (1981).

75. Laurence Helfer, Finding a Consensus on Equality: The Homosexual Age of Consent and the European Convention on Human Rights, 65 N.Y.U. L. Rev. 1044, 1045-1100 (1990).

76. Toonen, supra note 67 , at $226,235$.

77. Additionally, the ECHR cases are applicable only to the forty-seven Council of Europe member states. And, enforcement has been notoriously problematic: after Modinos, Cyprus refused to change its discriminatory laws for several years. Moreover, Toonen was a very limited holding that is open to a variety of interpretations. Its reliance upon continued judicial assignment of sexual orientation rights to clauses prohibiting discrimination based on "sex" has been questioned. Additionally, enforcement of the Commission ruling was very challenging, requiring Australia to invoke its "foreign relations power" and sue the province of Tasmania before the provincial legislature changed their law. See Douglas Sanders et al., Finding a Place in International Law, InT'L GAY \& LesBIAN Ass'N (July 20, 1997), http://dossieractivista.no.sapo.pt/place_interna tional_law.htm.

Very few international human rights bodies have evidenced the kind of unequivocal prohibition of discrimination on the basis of sexual orientation as the Technical Committee read into contemporary precedent. International law, at its best, has been inconsistent. See O'Flaherty \& Fisher, supra note 69, at 228; see also AMNESTY INT'L, supra note 65, at 38-39.

78. Explanatory Memoranda, supra note 59, at 10, § 6.1.

79. See Carl F. Stychin, a Nation by Rights: National Cultures, Sexual Identity Politics, ANd the Discourse of Rights 74-75 (1988). Based in Johannesburg, NCGLE was formed in December 1994 in anticipation of the struggle to keep sexual orientation in the final Constitution's non-discrimination clause. It coordinated national efforts on behalf of a loose association of seventy-three member organizations. NCGLE's activities were meant to supplement the continued activities of the other South African gay and lesbian groups. Christiansen, Ending the Apartheid of the Closet, supra note 25, at 1037 
lobbying to senior Constitutional Assembly decision-makers. ${ }^{80}$ Secondarily it sought to influence the Public Participation Programme, hoping to demonstrate popular support to maintain explicit sexual orientation protections in the final constitution. ${ }^{81}$ During the drafting period, NCGLE's work included coordinating Coalition member actions, organizing lobbying efforts that reflected the racial and linguistic diversity of gay and lesbian South Africans, preparing submissions to the Constitutional Assembly, and orchestrating pro-gay letter-writing, petitions, and postcard campaigns. ${ }^{82}$ Following the coming into force of the 1996 Constitution, NCGLE also inaugurated its very successful litigation strategy, which will be discussed later in this Article. ${ }^{83}$

\section{iii. Organized Opposition to Sexual Orientation Protections}

It should be acknowledged at the outset of this discussion of formal opposition that the Public Participation Programme and outside studies of general population attitudes toward homosexuality in South Africa in the 1990s reflect significant antipathy toward gays and lesbians. ${ }^{84}$ However, only one political party, the African Christian Democratic Party (ACDP), ${ }^{85}$ formally fought inclusion of sexual orientation protections in the final constitution. ${ }^{86}$ The party based its opposition on a call for all political decisions to reflect the party's interpretation of biblical values. ${ }^{87}$ According to

(citing Bob Drogin, South Africa Gays Chalk Up New Rights to Nation's Cruel History; During Blacks' Struggle, Homosexual Activists Got Support from Anti-Apartheid Leaders. Constitution Now Protects Them from Bias, L.A. TIMEs, Dec. 13, 1996, at A5).

80. Jacklyn Cock, Engendering Gay and Lesbian Rights: The Equality Clause in the South African Constitution, 26 Women's Stud. Int'L F. 35, 37 (2003).

81. See Stychin, supra note 79.

82. Press Release, Int'l Gay \& Lesbian Human Rights Comm'n, Historic South African Bill of Rights Includes Sexual Orientation (May 1, 1996), http://www.qrd.org/qrd/ world/africa/south_africa/constitution.includes.sexual.orienatation-05.01.96.

83. See infra Sections III.A and III.B for discussion of the primary cases supported by NCGLE.

84. David Bilchitz, Constitutional Change and Participation of LGBTI Groups: A case study in South Africa, Int'l Inst. for Democracy \& Electoral Assistance 1, 13 (2015), http://www.constitutionnet.org/files/constitutional-change-and-participation-of-lgbtigroups-a-case-study-of-south-africa-pdf.pdf.

85. The ACDP, the smallest party in the Constitutional Assembly, was founded in 1994 by Kenneth Meshoe, a Christ for All Nations evangelical minister claiming an instruction from his god to found a political party based on "biblical values." Reverend Kenneth Meshoe's Testimony, Afr. Christian Democratic Party, http://www.acdp.org.za/ faq_testimony.asp (last visited June 28, 2000); see also Paul Stober \& Barbara Ludman, A-Z of South African Politics 224 (Paul Stobler \& Barbara Ludman eds., 2005) [hereinafter STOBER].

86. One of the twelve reasons the ACDP opposed the final Constitutions states: "The ACDP rejects the horizontal application of the equality clause [sic] in Chapter 2 of the Bill of Rights. We do not want Gays and Lesbians who are protected by the 'sexual orientation' clause in subsection 9(3) to be imposed on us. We want the right not to employ them, if we so wish, and not to have them teach our children their immoral, unnatural[,] and sinful lifestyles." 12 Reasons Why the ACDP Voted Against the Adoption on the South African Constitution, IAFrICA, http://users.iafrica.com/a/ac/acdp/constit .html (last visited Sept. 6, 2016).

87. See Gustavo Gomes da Costa Santos, Decriminalising homosexuality in Africa: lessons from the South African experience, in Human Rights, Sexual Orientation and 
the ACDP, inclusion of anti-discrimination protection for gays and lesbians was "against the will of God and African culture." 88

Furthermore, in its attempts to persuade the Constitutional Assembly to remove sexual orientation protections, the ACDP asserted that inclusion of sexual orientation in the Equality Clause amounted to special rights. ${ }^{89}$ The party also raised the specters of mandated same-sex marriage ${ }^{90}$ and exposure of children to "immoral, unnatural[,] and sinful lifestyles." 91 Although the ACDP was the smallest political party in the Constitutional Assembly-having won only two out of four hundred seats in the National Assembly in the 1994 elections ${ }^{92}$-support for its conservative positions was far greater than its electoral results indicated. ${ }^{93}$ Indeed, significant numbers of religious conservatives opposed the inclusion of sexual orientation protections even though they were politically aligned with parties, such as the ANC, who supported it. ${ }^{94}$

Nevertheless, other than the ACDP and some conservative religious groups, there was very limited formal or institutional opposition to the inclusion of sexual orientation during the drafting of the final constitution. ${ }^{95}$ But there was significant evidence of unfavorable public sentiment, in the form of petitions received through the Constitutional Assembly's Public Participation Programme. ${ }^{96}$

\section{iv. Sexual Orientation in the Public Participation Programme}

The various elements of the final constitution's drafting process were all occurring simultaneously. While the Theme Committees were drafting proposed text, elected representatives were expressing their public positions and party elites were negotiating the most sensitive outcomes, popu-

Gender Identity in the Commonwealth 313, 313-34 (Corinne Lennox \& Matthew Waites eds., 2013).

88. Constitutional Talk, vol. 1, supra note 26.

89. According to the ACDP, inclusion of sexual orientation as a protected category yields "preferential protection" that is open to all sorts of abuses including "the right to homosexuality, bestiality, pedophilia[,] and other "perverse sexual activity." ConstituTIONAL TALK, vol. 8, supra note 26.

90. For example: "What people do not realise is that this clause puts us priests in a lot of trouble .... What it means is that if two people of the same sex come to my church and ask me to marry them, if I refuse on grounds that they are of the same sex, they have recourse to the law .... . We have to test the will of the people on this issue .... And I am sure the majority of our people would not allow such marriages to be legalised. This is against the will of God and African culture." Id.

91. Id.

92. See Reynolds, supra note 18, at 183.

93. See STYChin, supra note 79 , at 80.

94. At the May 1995 National Sector Public Hearing for Religious Groups, several religious leaders declared that the sexual orientation clause was not necessary as there was sufficient protection in other rights. Mr. Mokabane of Concerned Evangelicals and Rev. Steele, of the International Fellowship of Christian Churches, spoke against inclusion of protections for gays and lesbians, reciting arguments similar to the ACDP party position. The general focus of the meeting was on church-state issues and rights of free exercise. Christiansen, Ending the Apartheid of the Closet, supra note 25, at 1039-40.

95. See StOBER, supra note 85.

96. Christiansen, Ending the Apartheid of the Closet, supra note 25, at 1039-40. 
lar input was also being sought. ${ }^{97}$ And, debate over inclusion of sexual orientation protections in the final constitution figured prominently in the Public Participation Programme. ${ }^{98}$ Sexual orientation protections were identified as a "hot topic" early in the process. In fact, retention of sexual orientation in the Equality Clause was mentioned in over 800 of the individual public comments and in petitions bearing over 24,000 signatures. ${ }^{99}$ A significant majority of individual submissions in the Programme supported inclusion-perhaps as a result of the efforts of NCGLE-but petition signatures gathered by conservative churches advocated removal of protections by more than a two-to-one margin over signatories supporting retention. 100

Very few of the Programme's public submissions are lengthy or thoughtful. Most are in the form of petitions or follow a common script. Submissions in support of inclusion followed certain trends. Most supporters wanted to "keep sexual orientation in the Constitution," expressing approval for the protective status quo created by the Interim Constitution. ${ }^{101}$ To the extent that the writers expressed a reason for inclusion, they most often cited general anti-discrimination arguments: 102 "Discrimination for one means discrimination for all, we cannot have a truly democratic society when any section of the population is discriminated against"; 103 and, "I don't work any different, I don't sleep any different, I

97. Thabo Mbeki, Representative ANC of South Africa, Statement at the General Assembly of the U.N. (Dec. 13, 1993), https://www.nelsonmandela.org/omalley/index .php/site/q/03lv02039/04lv02103/05lv02117/06lv02118.htm; see also Chapter 10 - A Framework for Negotiating the Final Constitution, S. Afr. Hist. OnLine, http://www.sahis tory.org.za/archive/chapter-10-framework-negotiating-final-constitution (last visited Sept. 11, 2016).

98. The Programme can be divided into two separate public comment periods, one from formation of the Constitutional Assembly in May 1994 until mid-1995 and another from publication of the working draft in November 1995 until February 20, 1996. In the period of response to the working draft alone, $56 \%$ of the total comments addressed articles of the Bill of Rights. See Constitutional Talk, vol. 2, supra note 26.

99. This total is based on figures reported by the Constitutional Assembly: petitioners opposed during first phase, 16,663; petitioners supporting inclusion in first phase, none reported; petitioners opposed during second phase, 546; and petitioners supporting inclusion during second phase, 7,032. See generally Marion SPARD, The Constitutional Assembly: Annual Report (1996).

100. All submissions are identified by their unique identifier number assigned by the Public Participation Programme staff at the time the submission was received. All of the submissions were available on a searchable database at www.constitution.org.za/form .html. The nature of the database and the fact that many of the submissions address multiple issues make it impossible to offer exact numbers, but an examination within those constraints reveals that there are three or four supportive submissions (from individuals) for every letter of opposition. Frustratingly, the internet source for these documents has been offline for a considerable amount of time and remains unavailable electronically. Julien Hofman, The Constitutional Assembly Database Project - Resurrecting a Database Ten Years On, 35 Int'L J. Legal Info. 79, 79 (2007).

101. Id.

102. See, e.g., N. Webster, Submission \#8319, Constitutional Talk, vol. 2, supra note 26; K. McConnell, Submission \#6152, Constitutional Talk, vol. 2, supra note 26.

103. See V. Smith, Submission \#7289, Constitutional Talk, vol. 2, supra note 26. 
don't love any different, I don't want to be treated any different."104 Many of the writers identified themselves as lesbians or gay men, ${ }^{105}$ although far more contributors expressly identified as heterosexual. ${ }^{106}$ At least a few submissions made reference to the broader implications of South Africa's equality protections: "The clause in the interim constitution-including sexual orientation should remain as is . . serving as an example and a forerunner for equality to other countries." 107

The submissions from those who opposed retention of sexual orientation in the constitution were significantly different in form as well as substance. For example, most were petitions rather than individually authored comments. A typical signed petition from an early stage states:

I hereby strongly object to the legalisation of immoral and unnatural sexual lifestyles under Chapter 3 Paragraph 8.2 of our interim constitution. The phrase "SEXUAL ORIENTATION" must be deleted from our present constitution and must NOT be included in the final constitution that is being drafted. Homosexuality, lesbianism, sodomy[,] and bestiality are unnatural, abnormal[,] and immoral and do not deserve any constitutional protection under clauses like "sexual orientation." 108

The overwhelming majority of opposition submissions based their argument on fundamentalist Christian notions of sexual morality. ${ }^{109}$ In addition to opposing equality based on sexual orientation, those submissions also often disfavored other progressive aspects of the constitution, such as abortion rights and the abolition of the death penalty. ${ }^{110}$

Another common characteristic of the opposing submissions was their vehemence: "How can any disgusting, deviant sexual behaviour have the phrase 'fundamental rights' protecting it?"111 For progressive South Africans who hoped that the inclusion of sexual orientation protection in the Interim Constitution two years earlier provided evidence of a new era of acceptance, these vituperative submissions must have been disheartening.

104. See C. Minnar, Submission \#7149, Constitutional Talk, vol. 2, supra note 26 (capitalization altered).

105. See, e.g., D. Renge, Submission \#6036, Constitutional Talk, vol. 2, supra note 26.

106. See, e.g., R. Hitzenroth, Submission \#6008, Constitutional Talk, vol. 2, supra note 26.

107. See Buitendag, Submission \#6024, Constitutional Talk, vol. 2, supra note 26.

108. See "Petition," Submission \#5601, Constitutional Talk, vol. 2, supra note 26 (The commentary preceding this submission states: "The [C]onstitutional [A]ssembly has received 16,363 copies of the following and similar petitions concerning the sexual orientation clause in the [I]nterim [C]onstitution").

109. See, e.g., Browne, Submission \#5577, Constitutional Talk, vol. 2, supra note 26; Abraham, Submission \#6591, Constitutional Talk, vol. 9, supra note 26.

110. Many petitions also opposed the proposed legality of abortion and the abolition of the death penalty. Others disliked the absence of explicit reference to God. See, e.g., MacGregor, et al., Submission \#3372, Constitutional Talk, vol. 2, supra note 26; Submission \#5062, Constitutional Talk, vol. 2, supra note 26.

111. See Taylor, Submission \#6794, Constitutional Talk, vol. 2, supra note 26. 


\section{v. Sexual Orientation is Included in the Final Constitution}

The Public Participation Programme culminated a few months prior to the completion of the Constitutional Assembly's drafting responsibilities. ${ }^{112}$ In the last, somewhat feverish few months of the drafting period, many final decisions were made outside of public scrutiny. ${ }^{113}$ Several factors contributed to this. The Theme Committees had finished much of their work, the working draft was published and was being distributed, and a significant number of political compromises needed to be made prior to consideration of the text by the whole Constitutional Assembly. ${ }^{114}$ The negotiations in the party-based Constitutional Committee-where ultimate authority rested-and other informal negotiations were neither recorded nor reported. ${ }^{115}$ Thus, it is difficult to know anything significant about these discussions other than the results of the process.

On October 10, 1995, the Constitutional Committee agreed to follow the Technical Committee's recommendations on several important issuesincluding retention of the Interim Constitution's explicit reference to sexual orientation in the final constitution. ${ }^{116}$ Due to this decision, Section Nine of South Africa's new constitution, "Equality," would prominently include protections for gays and lesbians:

9. (1) Everyone is equal before the law and has the right to equal protection and benefit of the law ....

(3) The state may not unfairly discriminate directly or indirectly against anyone on one or more grounds, including race, gender, sex, pregnancy, marital status, ethnic or social origin, colour, sexual orientation, age, disability, religion, conscience, belief, culture, language, and birth.

(4) No person may unfairly discriminate directly or indirectly against anyone on one or more grounds in terms of subsection (3). National legislation must be enacted to prevent or prohibit unfair discrimination . . . 117

Just as the Bill of Rights is "a cornerstone of democracy in South Africa," 118 the Equality provisions form a cornerstone of the Bill of Rights itself. Despite significant public opposition, limited legal precedent, relatively inexperienced civil society groups, and a conservative cultural back-

112. Public Participation, Parliament Rep. S. Africa, http://www.parliament.gov.za/ live/content.php?Category_ID=21 ("Since the advent of democracy in 1994, it has become possible for all citizens to get involved in what is happening in Parliament.").

113. Sarkin, supra note 20 , at $71-75$.

114. Id. at 68.

115. Heinz Kluz, Constituting Democracy Law, Globalism and South Africa's Political Reconstruction 100 (Cambridge Univ. Press 2000).

116. Eric C. Christiansen, Substantive Equality and Sexual Orientation: Lessons from Twenty Years of Gay and Lesbian Rights under the South African Constitution 3 (Nov. 10, 2014) [hereinafter Christiansen, Substantive Equality and Sexual Orientation] (unpublished manuscript) (on file with the New York Law School Law Review).

117. S. Afr. Const., 1996 (emphasis added). The only other explicit reference is Section 35 of the Bill of Rights which secures the right of a "spouse or partner" to visit a detained or imprisoned person. Id. § 35(2)(i).

118. Id. 
ground, gays and lesbians held on to their groundbreaking protections in the final South African Constitution.

\section{B. Explaining Gay Equality in the Constitutional Drafting Process}

At the end of the apartheid era in the late 1980s, South African gays and lesbians were poorly organized politically, racially divided, and generally despised. ${ }^{119}$ Before the ratification of the post-apartheid constitution, no domestic legal precedent existed for treating gays and lesbians other than as criminals. ${ }^{120}$ Anti-gay sentiment was high. ${ }^{121}$ And yet, within a few years, gay South Africans possessed a level of constitutional protection greater than that of any other nation-a level of legal protection that remains pre-eminent twenty years later.

How did South Africa-a deeply religious and conservative southern African nation-become the first country to include constitutional protections for gays and lesbians? The answer involves a unique convergence of elements at the time apartheid was ending in South Africa. ${ }^{122}$ These elements include historical, ideological, and procedural influences unique to South Africa in the 1990s. ${ }^{123}$

\section{The Role of History and Timing}

The confluence of three factors set the stage for an evolution in the legal status of gays and lesbians in a new, multi-racial South Africa. The three factors were the simultaneous maturation of the ANC and the burgeoning South African gay community; newly formed linkages between those two previously distinct liberation movements; and new favorable international legal protections related to sexual orientation. ${ }^{124}$

In South Africa, gay and lesbian organizing began to achieve some legitimacy in the late 1980s and early 1990s. ${ }^{125}$ After years of intentionally apolitical organizing, new and politically active gay groups that saw themselves as a part of the larger anti-apartheid movement were being established. Explicit identification with the liberation movements and rec-

119. See Ebrahim, supra note 14, at 239-50 (detailing the successes of the Public Participation Program in engaging the public); see also Constitutional Talk, vol. 9, supra note 26 (noting the citizen's involvement in the Public Participation Program).

120. Christiansen, Ending the Apartheid of the Closet, supra note 25, at 1000

121. Even as the apartheid government was lifting criminal sanctions against interracial sexual activity in 1988, the Parliament was considering an expansion of laws against same-sex sexual activity. Cameron, Unapprehended Felons, supra note 48, at 96. A 1987 survey of Cape Town residents (conventionally considered the most liberal town in all Africa) revealed that $71 \%$ believed homosexuality to be morally wrong. GORDON IsAACS \& Brian McKendrick, Male Homosexuality in South Africa: Identity, Information, Culture, ANd Crisis 141 (1992).

122. I have struggled to bring historical analysis to the novel and somewhat surprising results of the constitutional process for gays and lesbians in South Africa in a prior publication, so the description below is a summary of that analysis. Christiansen, Ending the Apartheid of the Closet, supra note 25.

123. See id. at 1042-56.

124. Id.

125. Id. at 1044 . 
ognition of the importance of multi-racial organizing represented an important new development. Furthermore, a host of unrelated occurrences brought activists and the ANC into direct contact with each other in the final years of apartheid. These included, for example, the forced outing of an anti-apartheid leader and the reporting of some anti-gay remarks by a prominent ANC figure. Both developments highlighted the involvement of gays, lesbians, and their supporters in the broader anti-apartheid movement. ${ }^{126}$ These and other events ultimately motivated the ANC's initial statements affirming the importance of equality based on sexual orientation. ${ }^{127}$

Outside of South Africa, international human rights bodies were recognizing changes in the legal status of gays and lesbians for the first time in history. The previously singular-and surprising pro-gay-international law precedent relating to sexual orientation announced by the European Court of Human Rights in its Dudgeon decision in $1981^{128}$ was affirmed in Norris in $1991^{129}$ and in Modinos in 1994. ${ }^{130}$ One year later, the United Nations Human Rights Commission relied on the International Covenant on Civil and Political Rights to denounce the criminalization of sex between men in the Australian province of Tasmania. ${ }^{131}$ The timing was fortuitous; these last two pro-gay decisions were announced during the constitutional drafting period. ${ }^{132}$

\section{Ideology and Non-Racialism}

The ANC and other groups within the liberation movement first stated the goal of a non-discriminatory South Africa in the 1955 Freedom Charter. ${ }^{133}$ "Non-racialism," expressed negatively as non-discrimination and positively as substantive equality, animated ANC discourse throughout its history. ${ }^{134}$ This dream of a renewed South Africa, a state founded on the principles of equality, multi-racial democracy, and human dignity, continued throughout the years of exile. ${ }^{135}$ Such philosophical underpinnings of the constitution were meant to repudiate apartheid's legal norms. They also allowed NCGLE to argue for gay and lesbian equality in a rights-rich ideological environment.

126. See Fine \& Nicol, supra note 47, at 270; see also Mark Gevisser, A Different Fight for Freedom: A History of South African Lesbian and Gay Organization from the 1950s to 1990s, in Defiant Desires, supra note 47, 14, 70 (reporting additional comments: "The gays have no problems ... I don't see them suffering. No one is persecuting them").

127. See Fine \& Nicol, supra note 47 , at 270.

128. See generally Dudgeon v. United Kingdom, App. No. 7525/76, 45 Eur. Ct. H.R. 20 (1981) (reserving the question of whether Irish law discriminated against homosexual acts).

129. Norris v. Ireland, App. No. 10581/83, 13 Eur. Ct. H.R. 186 (1991).

130. Modinos v. Cyprus, App. No. 15070/89, 16 Eur. H.R. Rep. 485, 494 (1993).

131. See Toonen, supra note 67, para. 9.

132. See Sarkin, supra note 20, at 68.

133. The Freedom Charter of 1955 (S. Afr.).

134. Christiansen, Ending The Apartheid of the Closet, supra note 25, at 1046.

135. Id. 
As a philosophy, non-racialism espoused an end to all forms of discrimination and the inviolability of human rights by the state. It also acted as a tool for ending apartheid, creating a democratic government, and healing the nation. This same tool was wielded in the pre-drafting era and throughout the drafting periods to promote inclusion of sexual orientation as an additional protected category. ${ }^{136}$ The presumptive inclusion of sexual orientation as a basis for protection, combined with the centrality of non-racialism in ANC discourse about a post-apartheid nation, strongly supported the development of anti-discrimination policies that included express protections for gays and lesbians.

\section{Constrained Drafting Process}

The third factor contributing to the inclusion of protections for gays and lesbians was the particular method of drafting the South African Constitution. The final draft of the constitution was the result of a sequential process that moved from draft to draft under tight time constraints and strong political pressure. ${ }^{137}$ Party-based negotiating committees made the earliest decisions-and most of the weightiest decisions throughout the process-behind closed doors. Additionally, small groups-including theme committees of experts for the interim text and technical committees in the final drafting process-directed most of the textual revisions. Furthermore, the party-based Constitutional Committee approved most final elements before the last draft was put to a vote-a vote uniformly decided along party lines.

The consequence of this controlled, sequential process with a limited number of only indirectly accountable drafters was a final text determined mostly by experts and party elites. Gay and lesbian advocates were beneficiaries of this process because their concerns were congruent with the dominant ideology of the process and several important constitutional actors were outspoken in their support.

Hence, the stage for this unprecedented protection was set by the unique history of South Africa and its gay and lesbian citizens. The call for gay and lesbian equality emerged contemporaneously with the fundamental constitutional re-creation of a state that had existed for forty-seven years with discrimination as its primary political and social reality. The dominant ideology of liberation movement elites provided the justification for such an innovative legal protection, allowing sexual orientation protections to be included as a presumptive corollary of the ANC policy of non-racialism. Additionally, a highly structured and political party-controlled constitutional drafting process allowed codification of a progressive human rights standard, including explicit protections for gays and lesbians, despite uncertain claims of support from the public and international law precedent. 


\section{Gay and Lesbian Rights at the South African Constitutional Court}

Having secured ratification of the first constitution to include express protections based on sexual orientation, many gay and lesbian activists had high hopes. In the years that followed, the South African Constitutional Court repeatedly rose to the challenge presented by the fact of this unprecedented legal protection for an unpopular segment of South African society. In its first two decades, the Court decided six cases related to the sexual orientation provision of the Equality Clause. ${ }^{138}$ In each of its judgments, which included constitutional review of the criminalization of same-sex sexual activity, the application of laws related to family formation, and the recognition of same-sex relationships, the Court unanimously affirmed the full legal equality of the gay and lesbian parties before it.

The primary focus of the discussion below is the dramatic cases that start and conclude the arc of gay rights victories in the last two decades: the decriminalization of sodomy in 1998 and the requirement of full marriage equality in 2005 .

\section{A. Decriminalization in the NCGLE Sodomy Case}

In the 1998 decision of NCGLE v. Minister of Justice ("NCGLE Sodomy case"), the South African Constitutional Court decriminalized consensual same-sex sexual activity between adult males. ${ }^{139}$ The unanimous decision confirmed a lower court ruling ${ }^{140}$ that declared unconstitutional the common law offense of sodomy and struck down provisions of the Sexual Offences Act that criminalized certain vaguely-defined acts between

138. Minister of Home Affairs v. Fourie 2005 (1) SA 524 (CC) at 2, 5 paras. 2,6 (S. Afr.) (citing Fourie v. Minister of Home Affairs (Oct. 2002) No. 17280/02 (unpublished)); $J$ and B v. Dir. Gen., Dep't of Home Affairs \& Others 2003 (5) SA 621 (CC) (S. Afr.); Du Toit \& Another v. Minister of Welfare and Population Dev. \& Others 2003 (2) SA 198 (CC) (S. Afr.); Satchwell v. President of Rep. of S. Afr. 2002 (6) SA 1 (CC) (S. Afr) (granting remuneration and pension benefits to same-sex partners); Nat'l Coal. for Gay and Lesbian Equal. \& Others v. Minister of Home Affairs \& Others 1999 (2) SA 1 (CC) (S. Afr.) [hereinafter NCGLE Immigration]; Nat'l Coal. for Gay and Lesbian Equal. v. Minister of Justice and Others 1999 (1) SA 6 (CC) (S. Afr.) [hereinafter NCGLE Sodomy]. References to Fourie in the remainder of this Article refer to the 2005 Constitutional Court case.

139. See, e.g., Du Toit 2003 (2) SA 198 (CC) at 16 para. 21 (S. Afr.); Satchwell 2002 (6) SA 1 (CC) at 17 para. 21 (S. Afr); NCGLE Immigration 1999 (2) SA l (CC) at 48-49 para 58 (S. Afr.); NCGLE Sodomy 1999 (2) SA 1 (CC) at para. 21 (S. Afr.).

140. Nat'l Coal. for Gay \& Lesbian Equal. \& Others v. Minister of Justice \& Others 1998 (6) BCLR 726 (W) at para. 2 (S. Afr.) [hereinafter NCGLE]. The Witwatersrand High Court also struck down the common law offenses of sodomy and commission of an unnatural sexual act to the extent it criminalized acts "committed by a man or between men which, if committed by a woman or between women or between a man and a woman, would not constitute an offence." These rulings were not referred to the Constitutional Court because a High Court (a South African trial court) is not required to refer declarations of constitutional invalidity of common law offences to the Court. NCGLE Sodomy 1999 (2) SA 1 (CC) at para. 2 (S. Afr.) (following the \& 172(2)(a) requirement that declaration of constitutional invalidity of "an Act of parliament, a provincial Act or any conduct of the President" must be confirmed by the Constitutional Court to have force, but having no such requirement for common law rules). 
men. ${ }^{141}$ Writing for the unanimous Court, Justice Ackermann held that the common law and statutory offenses of sodomy violated the equality, dignity, and privacy rights provided in the South African Constitution. ${ }^{142}$

On the central issue of equality, Ackermann applied what is now the standard analysis for all discrimination questions. Indeed, the NCGLE Sodomy case marked the first application of the Equality Clause from the 1996 Constitution and it continues to be cited as one of the seminal descriptions of the multi-stage inquiry South African courts use to evaluate discrimination claims. ${ }^{143}$ The core questions are: (1) Does the act discriminate? (2) Is the discrimination unfair? and (3) Can the unfair discrimination be justified? ${ }^{144}$

The first inquiry merely asks the parties to identify the differential treatment under law; in other words, are similarly situated persons or classes of people treated differently? ${ }^{145}$ Notably, non-biased types of differential treatment are common and permissible. ${ }^{146}$ The second inquiry, therefore, is whether the discrimination is "unfair." Discrimination is presumed to be unfair if it is based on a classification enumerated in the Equality Clause: race, gender, sex, pregnancy, marital status, ethnic or social origin, color, sexual orientation, age, disability, religion, conscience, belief, culture, language, and birth. ${ }^{147}$ Otherwise, determination of unfairness is based on "the position of the complainants in society."148 Particular attention is paid to "whether they have suffered in the past from patterns of disadvantage," the character and purpose of the provision, and the impact on the "rights or interests of the complainants ...."149 In the NCGLE Sodomy case, the Court concluded:

(a) Gay men are a permanent minority in society and have suffered in the past from patterns of disadvantage. The impact is severe, affecting the dignity, personhood[,] and identity of gay men at a deep level . . . .

(b) [The sodomy prohibition] has no other purpose than to criminalise conduct which fails to conform with the moral or religious views of a section of society.

141. Sexual Offences Act of $1957 \S 20 \mathrm{~A}(1)$ (S. Afr.) ("A male person who commits with another male person at a party any act which is calculated to stimulate sexual passion or to give sexual gratification, shall be guilty of an offence."). Other statutory provisions detailing various state employment repercussions were also struck down. NCGLE Sodomy 1999 (2) SA 1 (CC) at para. 106 (S. Afr.).

142. NCGLE Sodomy 1999 (2) SA 1 (CC) at para. 30 (S. Afr.).

143. Christiansen, Substantive Equality and Sexual Orientation, supra note 116, at 15.

144. See NCGLE Sodomy 1999 (2) SA 1 (CC) at paras. 16-17 (S. Afr.) (laying out these questions and citing to several cases including Harksen $v$. Lane NO and Others 1997 (11) BCLR 1489 (CC) at para. 53 (S. Afr.)). While Harksen was decided under the Interim Constitution, the use by the Court in NCGLE Sodomy adopted the earlier framework for analysis into the equality jurisprudence under the 1996 Constitution.

145. See id.

146. Id.

147. NCGLE Sodomy 1999 (2) SA 1 (CC) at paras. 11, 13 (S. Afr.).

148. Id. at para. 19.

149. Id. (citing Harksen v. Lane NO and Others 1997 (11) BCLR 1489 (CC) paras. 50-51 (S. Afr.)). 
(c) The discrimination ... gravely affected the rights and interests of gay men and deeply impaired their fundamental dignity. ${ }^{150}$

The challenged sodomy laws, which targeted only same-sex sexual activity between men, were a presumptively unfair form of discrimination based on sexual orientation.

In the final stage of the inquiry, justification may exist if the differentiation, although unfair, satisfies the requirements of the Constitution's Limitations Clause. ${ }^{151}$ The South African Limitations Clause, like those in the German and Canadian Constitutions after which it was modeled, identifies a narrow set of justifications for an otherwise unconstitutional restriction on a person's rights. ${ }^{152}$ In South Africa, the limitation must be "reasonable and justifiable in an open and democratic society based on human dignity, equality[,] and freedom ...."153

Unfair discrimination that fails to be justified under the Limitations Clause is a violation of the Constitution and thus must be declared unconstitutional and remedied. "When deciding a constitutional matter within its power, a court-(a) must declare that any law or conduct that is inconsistent with the Constitution is invalid to the extent of its inconsistency; and (b) may make any order that is just and equitable ...."154 While the Court has no flexibility with the declaration of invalidity, it has significant discretion in relation to the remedy it grants to plaintiffs.

In the NCGLE Sodomy case, the Court held that the laws in question were not saved by Limitations Clause analysis:155 "[T]here is nothing which can be placed in the other balance of the scale. The inevitable conclusion is that the discrimination in question is unfair and therefore in breach of [the Equality Clause]." 156 Moreover, the Court conducted a significant survey of sodomy laws in Western democracies to demonstrate the trend of growing judicial disfavor, although it noted the then-precedential U.S. exception of Bowers v. Hardwick. ${ }^{157}$

150. Id. at para. 26.

151. Section 36(1) of the 1996 Constitution states:

The rights of the Bill of Rights may be limited only in terms of law of general application to the extent that the limitation is reasonable and justifiable in an open and democratic society based on human dignity, equality[,] and freedom, taking into account all relevant factors, including-(a) the nature of the right; (b) the importance of the purpose of the limitation; (c) the nature and extent of the limitation; (d) the relation between the limitation and its purpose; and (e) less restrictive means to achieve the purpose.

S. AFr. Const., 1996 \& 36(1).

152. Stephen Gardbaum, Limiting Constitutional Rights, 54 UCLA L. Rev. 789, 798-800, 840 (2007).

153. S. Afr. CONST., 1996 \& 36(1).

154. S. Afr. Const., 1996 \& 172(1).

155. Nat'l Coal. for Gay and Lesbian Equal. v. Minister of Justice and Others 1999 (1)

SA 6 (CC) at para. 27 (S. Afr.) [hereinafter NCGLE Sodomy].

156. Id.

157. Id. at paras. 53-54. See generally Bowers v. Hardwick, 478 U.S. 186 (1986), overruled by Lawrence v. Texas, 539 U.S. 558 (2003). The Court's opinion stressed the five-to-four nature of Bowers and the "sustained criticism" of its holding. In disregarding the American ruling, the Court highlighted the express nature of the sexual orientation 
In Ackerman's rather technical opinion, sexual orientation discrimination is just another kind of discrimination rejected in the Constitution. For loftier rights language, a reader need look no further than Justice Sachs's concurring opinion. Perhaps predictably, given his long-term concern for the equality of LGBT persons, Sachs's opinion affirms the broader importance of striking down sodomy laws and its symbolic significance for a new constitutional democracy:

Only in the most technical sense is this a case about who may penetrate whom where. At a practical and symbolical level it is about the status, moral citizenship[,] and sense of self-worth of a significant section of the community. At a more general and conceptual level, it concerns the nature of the open, democratic[,] and pluralistic society contemplated by the Constitution. ${ }^{158}$

Sachs clearly identified the limited but vital capacity of the Constitutional Court when evaluating gay rights issues. The remainder of his concurrence focuses on "complementary observations of the broader matters," giving him an opportunity to present some considered thoughts on the constitutional issues of privacy, dignity, and equality as highlighted by the case. ${ }^{159}$ This is not an uncommon practice in early Constitutional Court opinions, especially among justices deeply invested in an expansive and progressive understanding of the constitutional project, like Sachs. ${ }^{160}$

\section{B. Getting to the Altar: Family and Relationship Recognition}

Over the five years following NCGLE Sodomy, the Court handed down five additional rulings promoting equality based on sexual orientation. ${ }^{161}$ Each judgment was a unanimous decision; each was a victory for the gay plaintiffs; and each reaffirmed the Constitutional Court's fundamental commitment to a generous interpretation of South Africa's Equality Clause as it applied to lesbians and gay men. ${ }^{162}$

In the 1999 NCGLE Immigration case, the Court ruled that the equality protections required that "gays and lesbians who are permanent residents in the Republic and who are in permanent same-sex life partnerships with foreign nationals" receive treatment equal to that given married heterosexual persons in the immigration law context. ${ }^{163}$ To reach its proequality conclusion, the Court first discussed the nature of same-sex relationships-whether they resemble heterosexual relationships in quality and kind. ${ }^{164}$ The Court stated several conclusions about the nature of samesex relationships: "Gays and lesbians in same-sex life partnerships are as

protections and the fundamentally more protective nature of the South African Constitution.

158. NCGLE Sodomy 1999 (1) SA 6 (CC) at para. 107 (S. Afr.) (Sachs, J., concurring).

159. Id.

160. Letter from Albie Sachs, supra note 43.

161. See infra notes 163, 167, 172, 176, 187 and accompanying text.

162. Id.

163. Nat'l Coal. for Gay and Lesbian Equal. E Others v. Minister of Home Affairs \& Others 1999 (2) SA 1 (CC) at 48 para. 57 (S. Afr.) [hereinafter NCGLE Immigration].

164. See id. at 44-46 para. 53 . 
capable as heterosexual spouses of expressing and sharing love in its manifold forms ... [and] are likewise as capable of forming intimate, permanent, committed, monogamous, loyal[,] and enduring relationships ...." 165

Moreover, the Court affirmed the familial nature of gay relationships and their fundamental equality with heterosexual families: "they are capable of constituting a family, whether nuclear or extended, and of establishing, enjoying[,] and benefiting from family life which is not distinguishable in any significant respect from that of heterosexual spouses." 166 Such language, and its underlying legal presumptions, were important to the subsequent cases at the Court, most of which touched on the equality of gay families. After review of comparative remedies law and an affirmation of Parliament's capacity to refine the Court's action, the Court "cured" the challenged law by "reading in [to the effective text of the immigration law] after the word 'spouse,' the following words: 'or partner, in a permanent same-sex life partnership.'"167

In the 2002 Satchwell case, the Court held that the government must afford the same-sex partners of South African judges the same employment benefits provided to opposite-sex spouses. ${ }^{168}$ In a short, but (again) unanimous opinion, the Court ruled that:

Inasmuch as the [Act's provisions] afford benefits to spouses but not to same-sex partners who have established a permanent life relationship similar in other respects to marriage, including accepting the duty to support one another, such provisions constitute unfair discrimination. ${ }^{169}$

In just over a dozen substantive paragraphs that rely heavily on the discussion of family and respect for alternative forms of familial relationship in the NCGLE Immigration case, the Court affirmed the underlying lesbian relationship and decried the discrimination in the Remuneration Act. ${ }^{170}$ The Court had no difficulty saying that the petitioners lived "in every respect as a married couple and [were] acknowledged as such by their respective families and friends" and that their relationship was "intimate, committed, exclusive[,] and permanent." ${ }^{171}$ Notably, counsel for the

165. Id.

166. Id.

167. Id. at $59,61-62,67,69-70$ paras $73,77,86,89$. The Court concluded it had two options for remedies: to strike down the provision allowing (any) spouses to immigrate or to "read in" comparable benefits for same-sex life partners. The former option had the significant failing of being "equality with a vengeance," it created legal equality by stripping rights away from those legitimately benefiting from an otherwise constitutional provision with strong popular and legislative support. The latter option had the difficulty of being a novel verdict not previously applied by the Court. Here, the Court elected to "read in" a constitutional remedy that alters the effective text of the statute by inserting language to fix an unconstitutional fault in the original law. The order, unlike the order in NCGLE Sodomy, had no retrospective effect. Id. at para. 89.

168. Satchwell v. President of Rep. of S. Afr. 2002 (6) SA 1 (CC) at 18 para. 23 (S. Afr).

169. Id.

170. See id. at 10-12 paras. 12-13.

171. Id. at 4 para. 4 . 
Minister of Justice and Constitutional Development, representing the views of the government:

[C]onceded without qualification, correctly in [the Court's] view, that permanent same-sex life partners are entitled to found their relationships in a manner which accords with their sexual orientation and further that such relationships ought not to be the subject of unfair discrimination. ${ }^{172}$

In the 2003 DuToit case, the Court ruled that denial of second-parent adoption rights to gay couples violated their constitutional rights to equality and dignity, in addition to violating the "best interests of the child" standard required by the child welfare protections of the Constitution. ${ }^{173}$ The Act's limitation "perpetuate[d] the fiction or myth of family homogeneity based on the one mother/one father model. It ignore[d] developments that have taken place in the country, including the adoption of the [C]onstitution." 174 The Court concluded that the categorical exclusion of permanent same-sex couples from the possibility of joint adoption "surely defeat[ed] the very essence and social purpose of adoption which is to provide the stability, commitment, affection[,] and support important to a child's development ...."175 Among the Act's many faults, its prohibitions "deprive[d] children of the possibility of a loving and stable family life."176

Later that year, in the confidentially named case $J$ and $B$, the Court applied the same reasoning to a case regarding adoption following artificial insemination. ${ }^{177}$ In a very brief judgment, another unanimous Court ruled on behalf of the lesbian appellants. Consistent with the previous cases, the Court held that Section 5 of the Status Act unfairly distinguished married persons from permanent same-sex life partners. ${ }^{178}$ Section 5 discriminated by denying to same-sex partners a right granted to heterosexual married couples: for both partners to become the legal parents of children born from artificial insemination. ${ }^{179}$ The Court remedied the unconstitutional fault in the law by "reading in" the words "or permanent same-sex life partner" whenever wife or husband was mentioned. 180

These three rulings from 2002 and 2003 also evidenced the Court's increasing frustration with parliamentary inaction. ${ }^{181}$ Strong evidence had existed that the Court would rule against sexual orientation-based dis-

172. Writing for the Court, Justice Madala described this concession as "correct[ ] in my view." Id. at 13 para. 15.

173. Du Toit \& Another v. Minister of Welfare and Population Dev. E Others 2003 (2) SA 198 (CC) at 29-30 paras. 41-43 (S. Afr.).

174. Id. at 21 para. 28.

175. Id. at 16 para. 21.

176. Id. at 16-17 para. 22.

177. J and B v. Dir. Gen., Dep't of Home Affairs \& Others 2003 (5) SA 621 (CC) at para. 13 (S. Afr.).

178. Id.

179. Id. at para. 15 .

180. Id. at para. 28.

181. The fact that the government ministers did not actively oppose the gay and lesbian applicants in Satchwell, Du Toit, and J and B further suggests that the government did not believe there was a viable constitutional argument in opposition to the gay rights claim. See generally J and B 2003 (5) SA 621 (CC) (S. Afr.); Du Toit \& Another v. Minister 
crimination in family law generally and civil marriage laws specifically at least since the ruling in the NCLGE Immigration case. Indeed, it was difficult to imagine any other result once the text of the final constitution was certified in 1996. Nevertheless, Parliament had refused to address the extant discrimination in statutes (and the common law) or to take definitive action on the issue of marriage equality, refusing to act absent unequivocal pressure from the Court. ${ }^{182}$

Parliament failed to pass legislation that would bring South African family law into compliance with the equality mandate of the Constitution and the ANC neglected to apply sufficient pressure to advance such a remedy. ${ }^{183}$ The Court expressly declared its growing frustration in $J$ and B: "Comprehensive legislation regularizing relationships between gay and lesbian persons is necessary. It is unsatisfactory for the Courts to grant piecemeal relief to members of the gay and lesbian community as and when aspects of their relationships are found to be prejudiced by unconstitutional legislation ...."."184 The Court chided Parliament for its inaction, reminding its members that they were formally bound by the Constitution ${ }^{185}$ and that they had a constitutional duty to "respect, protect, promote[,] and fulfil the rights in the Bill of Rights." 186 The Executive and Legislature were therefore "obliged to deal comprehensively and timeously with existing unfair discrimination against gays and lesbians."187 Parliament did not-at least not until there was unequivocal judicial pressure.

\section{Marriage Equality at the Constitutional Court}

Marié Fourie and her girlfriend Cecelia Bonthuys had been together for nearly ten years when they brought suit for legal recognition of their relationship in the Pretoria High Court in 2002. ${ }^{188}$ The Court's legal conclusion, that the rights and privileges of marriage may not be denied on the basis of sexual orientation, was mostly unsurprising. 189 Nearly every element of the Fourie v. Minister of Home Affairs decision was dictated by

of Welfare and Population Dev. E Others 2003 (2) SA 198 (CC) (S. Afr.); Satchwell v. President of Rep. of S. Afr. 2002 (6) SA 1 (CC) (S. Afr.).

182. See generally J and B 2003 (5) SA 621 (CC) (S. Afr.); Du Toit 2003 (2) SA 198 (CC) (S. Afr.); Satchwell 2002 (6) SA 1 (CC) (S. Afr.).

183. See generally J and B 2003 (5) SA 621 (CC) (S. Afr.); Du Toit 2003 (2) SA 198 (CC) (S. Afr.); Satchwell 2002 (6) SA 1 (CC) (S. Afr.).

184. J and B 2003 (5) SA 621 (CC) at para. 23 (S. Afr.).

185. Id. at para. 25.

186. S. Afr. Const., $1996 \S 8(1)$ ("The Bill of Rights ... binds the legislature, the executive, the judiciary[,] and all organs of state.").

187. J and B 2003 (5) SA 621 (CC) at para. 25 (S. Afr.).

188. Minister of Home Affairs v. Fourie 2005 (1) SA 524 (CC) at paras. 2, 6 (S. Afr.).

189. Du Toit \& Another v. Minister of Welfare and Population Dev. \& Others 2003 (2) SA 198 (CC) (S. Afr.); Satchwell v. President of Rep. of S. Afr. 2002 (6) SA 1 (CC) (S. Afr.); Nat'l Coal. for Gay and Lesbian Equal. \& Others v. Minister of Home Affairs \& Others 1999 (2) SA 1 (CC) (S. Afr.) [hereinafter NCGLE Immigration]; Nat'l Coal. for Gay and Lesbian Equal. v. Minister of Justice and Others 1999 (1) SA 6 (CC) (S. Afr.) [hereinafter NCGLE Sodomy]. 
precedent. 190 The Court's unanimous substantive ruling was a relatively straightforward, incremental extension of existing precedent related to gay and lesbian equality in the realms of family formation and relationship recognition.

The Court held that:

[T]aking account of the decisions of this court, and bearing in mind the symbolic and practical impact that exclusion from marriage has on same-sex couples, there can only be one answer to the question as to whether or not such couples are denied equal protection and subjected to unfair discrimination. Clearly, they are, and in no small degree. ${ }^{191}$

The exclusion of same-sex couples from access to civil marriage was unfair discrimination because it was differential legal treatment on a prohibited basis, sexual orientation. ${ }^{192}$ The same-sex couple plaintiffs wanted South African law to "accept the reality of their presence, and the integrity in its own terms, of their intimate life ...."193 This had not occurred. Instead, "the law in the past failed to secure for same-sex couples the dignity, status, benefits[,] and responsibilities that it accords to heterosexual couples." ${ }^{194}$ The Court asserted that the gay and lesbian parties sought "the right to be acknowledged as equal and to be embraced with dignity by the law ...."195

Although the substantive holding was not significantly in doubt, the Court's remedy was surprising: a one-year delay in enforcing the order of invalidity. ${ }^{196}$ The Court could have directly and immediately fixed the problem Parliament refused to address: the absence of a comprehensive legal scheme addressing same-sex family relationships. In prior cases, the Court had used its expansive remedial powers to invalidate discriminatory laws or to "read in" necessary language to cure a constitutional defect. ${ }^{197}$ The Court took neither route in Fourie. Rather, it identified the constitutional fault but suspended its ruling of invalidity. ${ }^{198}$ The Court sent the deficient law back to Parliament and gave it twelve months to "cure the

190. See J and B 2003 (5) SA 621 (CC) (S. Afr.); Du Toit 2003 (2) SA 198 (CC) (S. Afr.); Satchwell 2002 (6) SA 1 (CC) (S. Afr.); NCGLE Immigration 1999 (2) SA 1 (CC) (S. Afr.); NCGLE Sodomy 1999 (1) SA 6 (CC) (S. Afr.).

191. Fourie 2005 (1) SA 524 (CC) at 49-50 para. 78 (S. Afr.).

192. Id. ("The common law and section 30(1) of the Marriage Act continue to deny to same-sex couples equal protection and benefit of the law ... and taken together result in same-sex couples being subjected to unfair discrimination by the state . ...").

193. Id.

194. Id.

195. Id.

196. Id. at 84-86 paras. 135-37.

197. See, e.g., Nat'l Coal. for Gay and Lesbian Equal. \& Others v. Minister of Home Affairs \& Others 1999 (2) SA 1 (CC) at 73-74 para. 98 (S. Afr.) [hereinafter NCGLE Immigration] ("[S]ection 25(5) of the Aliens Control Act 96 of 1991, is to be read as though the following words appear ....."); Nat'l Coal. for Gay and Lesbian Equal. v. Minister of Justice and Others 1999 (1) SA 6 (CC) at para. 2 (S. Afr.) [hereinafter NCGLE Sodomy] (invalidating: "It is declared that section 20A of the Sexual Offenses Act, 1957 is inconsistent with the Constitution and invalid").

198. Fourie 2005 (1) SA 524 (CC) at 100-01 para. 161 (S. Afr.). 
defect" in the Marriage Act. ${ }^{199}$

Parliament was ordered to address the discrimination in South African family law. Same-sex couples may not be "subjected to marginalization or exclusion by law either directly or indirectly." 200 At last, Parliament had to perform the task the Court had reminded them was theirs. As Justice Sachs said in Fourie, "It's not only the Court's duty to protect constitutional rights. In fact, [the duty is] mainly legislative."201 Parliament considered how precisely to end the "present exclusion of same-sex couples from enjoying the status and entitlements" of marriage." 202 The legislature's task was carefully circumscribed by both the general ruling in Fourie and the judgment's declaration of two mandatory "guiding principles" relevant to Parliament's assigned task. ${ }^{203}$

The first principle prohibited Parliament from achieving equality in marriage law by ending the state's role in marriage altogether. As the Court said it, "[l]evelling down so as to deny access to civil marriage to all would not promote the achievement of the enjoyment of equality ...."204 The second principle prohibited a separate but equal formulation for marriage. The parliamentary response could not create or employ produce "new forms of marginalization."205 Formal legal equality was not called for, substantive legal equality was required. Parliament must consider the real life implications of its decisions. The Court would not be blind to the context in which that happens; equality and dignity require concern for "the intangibles as well as the tangibles involved." 206 "Ignoring the context, once convenient, is no longer permissible ...."207 This second principle seemed intended to reject the proposed legislative solution of civil unions, as a lower tier of relationship recognition for gay couples. The prior identification of those two guiding principles saved the Court from further review of the marriage legislation passed by Parliament in 2006. ${ }^{208}$

199. In justifying its delay, the Court highlighted that much legislative work had already been done preparing Parliament to make a decision in this area. The Court noted that the South African Law Reform Commission was finalizing a legislative report and proposals. The Commission process had involved extensive public input, would be imminently available to the Minister of Justice and Constitutional Development (and through her to Parliament), and would be a comprehensive review of the necessary legal changes for formal recognition of same-sex family law arrangements. Id. at 81-82 paras. 130-31. The SALRC in fact noted that the Court ruling would aid it in its recommendations to Parliament. Id. at 81 para. 129 n. 124.

200. Id. at 81, 91 paras. 129 n.124, 147 .

201. Joe Katz, South African Judge Addresses Gay Marriage at Swift Hall, CHI. MAROON (Jan. 13, 2006), http://chicagomaroon.com/2006/01/13/south-african-judge-addressesgay-marriage-at-swift-hall/ (emphasis added).

202. Fourie 2005 (1) SA 524 (CC) at 91 para. 147 (S. Afr.).

203. Id. at 91-94, paras. 148-50.

204. Id. at 92 para. 149 .

205. Id. at 93-94 para. 150 .

206. Id. at 96 para. 153.

207. Id. at 94-95 para. 151.

208. See Civil Union Act 17 of 2006 (S. Afr.). 


\section{A South African Gay Rights Jurisprudence}

\section{A. Summarizing Twenty Years of Constitutional Adjudication}

The South African Constitutional Court's extant gay rights jurisprudence is the most affirmative constitutional gay rights jurisprudence of any national court in the world. In the twenty years since the Constitution came into force, the Court has repeatedly and forcefully held that the transformative constitutional values of equality and dignity forbid the state from denigrating or excluding gays and lesbians from full and equal citizenship based merely on their position as a traditionally disfavored minority. The Court's jurisprudence has been typified by three traits: robust engagement and impactful application of the prohibition of discrimination based on sexual orientation; sincere consideration and fair-minded assessment of the historical and social context of anti-gay discrimination; and unwavering commitment to advancing the transformative values of equality and dignity in the Constitution.

\section{Impactful Engagement}

Robust and impactful judicial engagement is the first characteristic that typifies the Constitutional Court in the area of gay and lesbian equality. In its first twenty years, the Court issued substantive holdings in a surprising number of high-profile gay rights cases. ${ }^{209}$ Indeed, all of the gay rights cases were heard in the first decade following the inauguration of the 1996 Constitution. ${ }^{210}$ The justices have not shied away from the controversy associated with their socially unpopular views affirming gay and lesbian equality. In its first case, the Court unflinchingly addressed the right to same-sex sexual activity, affirming the deeper dimensions and fundamental dignity concerns associated with the physical manifestations of human sexuality. ${ }^{211}$ In its most recent case, the Court embraced the most sharply contested modern gay rights claim: full equality in civil marriage. ${ }^{212}$ The justices have not been reticent to strike down discriminatory government policies and laws: "Although the Constitution itself cannot destroy homophobic prejudice it can require the elimination of the public institutions which are based on and perpetuate such prejudice."213

209. See, e.g., Fourie 2005 (1) SA 524 (CC) (S. Afr.); J and B v. Dir. Gen., Dep't of Home Affairs \& Others 2003 (5) SA 621 (CC) (S. Afr.); Du Toit \& Another v. Minister of Welfare and Population Dev. E Others 2003 (2) SA 198 (CC) (S. Afr.); Satchwell v. President of Rep. of S. Afr. 2002 (6) SA 1 (CC) (S. Afr.); Nat'l Coal. for Gay and Lesbian Equal. $\mathcal{E}$ Others v. Minister of Home Affairs \& Others 1999 (2) SA l (CC) (S. Afr.) [hereinafter NCGLE Immigration]; Nat'l Coal. for Gay and Lesbian Equal. v. Minister of Justice and Others 1999 (1) SA 6 (CC) (S. Afr.) [hereinafter NCGLE Sodomy].

210. See, e.g., Fourie 2005 (1) SA 524 (CC) (S. Afr.); J and B 2003 (5) SA 621 (CC) (S. Afr.); Du Toit 2003 (2) SA 198 (CC) (S. Afr.); Satchwell 2002 (6) SA 1 (CC) (S. Afr.); NCGLE Immigration 1999 (2) SA 1 (CC) (S. Afr.); NCGLE Sodomy 1999 (1) SA 6 (CC) (S. Afr.).

211. See generally NCGLE Sodomy 1999 (1) SA 6 (CC) (S. Afr.).

212. See generally Fourie 2005 (1) SA 524 (CC) (S. Afr.).

213. NCGLE Sodomy 1999 (1) SA 6 (CC) at para. 130 (S. Afr.). 
Moreover, the Court's judgments have been uniformly unanimous in result and have demonstrated little prevarication in their description of gay and lesbian individuals' rights or the value of same-sex relationships. ${ }^{214}$ Furthermore, support for gay and lesbian equality under the Constitution has not been the vanity project of a few justices; rather, a variety of justices have authored the lead opinions with significant, meaningful concurrences reinforcing the core holdings. ${ }^{215}$ There have been a total of five different lead authors (and two concurrences) for the Court's six sexual orientation cases. The justices have seemingly embraced their responsibility to advance equality and prohibit "marginalization or exclusion by law, either directly or indirectly." 216

Notably, the term "impactful engagement" is not intended as a euphemism for judicial activism. ${ }^{217}$ The Court's role is properly described as engagement rather than activism because the Court has stayed within the scope of the specific, live controversies brought properly before the Court. For example, although few scholars doubted the eventual result, the Court determined the unconstitutionality of the civil marriage limits related to sexual orientation only when the case was properly before the Court. ${ }^{218}$ The Court did not hesitate to assert the underlying equality of same-sex couples and their relationships in earlier cases, but it called upon Parliament to act rather than inserting itself into an insufficiently ripe dispute, as its holding in Fourie demonstrates. Moreover, there is a special role for judicial engagement in the enforcement and interpretation of a transformative-by-design constitution; judicial inaction (and perhaps even judicial moderation) might represent inappropriate ideological support for the status quo.

214. See Fourie 2005 (1) SA 524 (CC) (S. Afr.); J and B 2003 (5) SA 621 (CC) (S. Afr.); Du Toit 2003 (2) SA 198 (CC) (S. Afr.); Satchwell 2002 (6) SA 1 (CC) (S. Afr.); NCGLE Immigration 1999 (2) SA 1 (CC) (S. Afr.); NCGLE Sodomy 1999 (1) SA 6 (CC) (S. Afr.).

215. See Fourie 2005 (1) SA 524 (CC) (S. Afr.); J and B 2003 (5) SA 621 (CC) (S. Afr.); Du Toit 2003 (2) SA 198 (CC) (S. Afr.); Satchwell 2002 (6) SA 1 (CC) (S. Afr.); NCGLE Immigration 1999 (2) SA 1 (CC) (S. Afr.); NCGLE Sodomy 1999 (1) SA 6 (CC) (S. Afr.).

216. Fourie 2005 (1) SA 524 (CC) at 91 para. 147 (S. Afr.).

217. Like many American constitutional law scholars, I doubt the ultimate efficacy of the term "judicial activism," which is intended to refer to improper ideologically-based, result-oriented adjudication but in contemporary (American) discourse most often means only that the speaker disagrees with judge's or justice's reasoning or result.

218. Fourie v. Minister of Home Affairs 2003 (5) SA 301 (CC) at 7, 9-10 (S. Afr.) (denying a direct appeal to the Constitutional Court and requiring the parties to appeal to the Supreme Court of Appeal). The Supreme Court of Appeal, a lower South African court for purposes of constitutional claims, struck the statutory and common law marriage law even though the [common law definition] was not properly challenged by the parties before it. Fourie v. Minister of Home Affairs 2005 (3) SA 429 (SCA) (S. Afr.). In fact, the Fourie case was joined with a separate case when it was considered by the Constitutional Court in 2005. Lesbian and Gay Equality Project v Minister of Home Affairs 2006 (1) SA 524 (CC) (S. Afr.) (including a statutory challenge to the Marriage Act, Act 25 of 1961). 


\section{Contextual Assessment}

The Constitutional Court's commitment to understanding discrimination and protecting rights requires the Court to consider the existing discriminatory environment, as well as the framework of substantive equality built into the post-apartheid constitutions. For example, context was vital for the Court in its assessment of the impact of sodomy laws (even unenforced sodomy laws) on gay men. ${ }^{219}$ The Court identified the deeper dimensions of the law: "At a practical and symbolical level [these criminal laws were] about the status, moral citizenship[,] and sense of self-worth of a significant section of the community." 220

Context showed that sodomy laws had been used as a tool of oppression and as an expression of social disapproval-unacceptable under the new constitution. ${ }^{221}$ The Court declared it would not be blind to the environment in which discrimination happens; equality and dignity require a concern for the "intangible as well as the tangibles involved."222

The Court discussed existing animus toward gays and lesbians as an element of the background reality to be reflected in its decisions, not as a legally irrelevant fact to be ignored. The Court acknowledged the hurt of discrimination, as when it acknowledged that denial of recognition of same-sex relationships "has been wounding and the scars are evident in our society to this day." 223 Indeed, the Court expressly acknowledged the negativity with which gays and lesbians were commonly viewed in South Africa, but strongly affirmed that " $[\mathrm{t}]$ he ubiquity of a prejudice cannot support its legitimacy." 224

The importance of context was particularly evident in the discussion of religious arguments against marriage equality. Justice Sachs acknowledged the role of procreation in religious understandings of marriage, but denied its significance to a legal understanding of the institution. ${ }^{225}$ For the Court, the constitutional duty was both to take seriously the religious views of the majority of South Africans as well as to protect the rights of non-believers and minority faiths. ${ }^{226}$ "Certainly the Court cannot assess the correctness of particular biblical interpretations of sources of law but it can assess that marriage equality has no direct impact on marriages of traditional believers." 227 As a consequence, the judgment stated unequivocally that "[i]t would be out of order to employ the religious sentiments of some as a guide to the constitutional rights of others." 228 Directly addressing these dominant religious opinions enriched the Court's rulings by

219. See NCGLE Sodomy 1999 (1) SA 6 (CC) at para. 107 (S. Afr.).

220. Id.

221. Id. at para. 30 .

222. Fourie 2005 (1) SA 524 (CC) at 96 para. 153 (S. Afr.).

223. Id. at 49-50 para. 78 .

224. Id. at 71-72 para. 113 .

225. Id. at 54-55 paras. 85-87.

226. Id. at 55-56 para. 89 .

227. Id. at 58 para. 92 .

228. Id. 
acknowledging the social context. It more incisively distinguished the legal conclusion from the extant social reality.

Moreover, the Court's assignment of the task of realizing full marriage equality to Parliament while effectively prescribing the result ${ }^{229}$ demonstrated a sensitivity to social context-and political savvy-that demonstrably benefitted an unpopular sexual minority. The Court even set a timeline for the legislative action. The expected (and actual) result was that Parliament passed marriage equality legislation in compliance with the Fourie ruling. ${ }^{230}$ The ANC, the standard-bearers of the most notable liberation movement of the last century, as well as the overwhelmingly dominant domestic political party, became the immediate focus for marriage equality in South African law. ${ }^{231}$

The democratic legitimacy of a legislative resolution, ${ }^{232}$ the requirement of affirmative legislative support for gay and lesbian South Africans from the ANC, and the inevitable discussion of the meaning of gay rights in the context of South Africa's constitutional values, advanced the realization of equality both domestically and internationally. Moreover, the result diminishes the impression of marriage equality as first world, Western, and Northern hemisphere affectation. The example of enforceable prohibitions on discrimination based on sexual orientation and even marriage equality expanded the potential for LGBT equality globally.

\section{Transformative Values}

The third evident characteristic of the Constitutional Court's gay rights jurisprudence is its commitment to the transformative nature of the post-apartheid constitutions. The Constitution's commitment to expansive notions of equality is reflected in the Court's rulings and in its approach. In assessing rights under a transformative constitution, "[t]he crucial determinant will always be whether human dignity is enhanced or diminished and the achievement of equality is promoted or undermined by the measure concerned." 233 The Court's commitment to expansive, substantive equality rather than merely formal, legal equality has typified its approach to the cases discussed above. This is reflected in the Court's broad iteration of the plaintiffs' claims:

[T] he [gay and lesbian parties] in this matter seek ... not the right to be left alone, but the right to be acknowledged as equals and to be embraced with dignity by the law .... [T] he law in the past failed to secure for same-sex couples the dignity, status, benefits[,] and responsibilities that it accords to

229. Id. at 100-01 para. 161 (providing the read-in remedy if Parliament does not act within twelve months).

230. See generally Civil Union Act 17 of 2006 (S. Afr.).

231. Barry Bearak, Final Results Show Resounding Victory for A.N.C. in South Africa, N.Y. Times (Apr. 26, 2009), http://www.nytimes.com/2009/04/26/world/africa/26SAF RICA.html (describing the ANC's election victory with $66 \%$ of the April 2009 vote).

232. Fourie 2005 (1) SA 524 (CC) at 108-09 para. 171 (S. Afr.) (O'Regan, J., concurring).

233. Id. at 95-96 para. 152 . 
heterosexual couples. ${ }^{234}$

Moreover, the cases were not just about the plaintiffs and their discrimination claims, they were about the values of the nation. Of course, the Court's jurisprudence removed criminal proscription, granted access to state-sponsored benefits, and ensured government recognition of relationships, but "[a]t a more general and conceptual level, it concern[ed] the nature of the open, democratic[,] and pluralistic society contemplated by the Constitution."235 Each case served not only the particular gay or lesbian plaintiffs, but the new-born constitutional democracy "in which government is based on the will of the people and every citizen is equally protected by law." 236 The Court understood its institutional role of providing support for the rights-focused transformation started with the Interim Constitution. And, it clearly believed its gay rights decisions have successfully done so: "From today a section of the community can feel the equal concern and regard of the Constitution and enjoy lives less threatened, less lonely and more dignified. The law catches up with an evolving social reality." 237

Alas, legal decisions are limited in their impact. The Court's success in invoking constitutional principles to invalidate biased legal rules almost exclusively impacts laws and actions of government institutions. As we shall see below, achieving positive effects on the day-to-day experience of bias and discrimination faced by gays and lesbians has proven to be much more difficult.

\section{B. The Inadequacy of Constitutional Law Protections}

Sadly, the legal protections are only one side of the story of sexual orientation discrimination in South Africa. Indeed, for many gay South Africans, the Constitution plays only a small part of the overall story-a part that does not include their lived reality. The broad legal protections must be contrasted with widespread social disapproval of homosexuality, recurrent and routine discrimination, and the dramatic prevalence of hate crimes, especially crimes of homophobic violence. ${ }^{238}$

234. Id. at 49-50 para. 78 .

235. Nat'l Coal. for Gay and Lesbian Equal. v. Minister of Justice and Others 1999 (1) SA 6 (CC) at para. 107 (S. Afr.) [hereinafter NCGLE Sodomy] (Sachs, J., concurring).

236. S. Afr. CONST., 1996, pmbl.

237. NCGLE Sodomy 1999 (1) SA 6 (CC) at para. 130 (S. Afr.).

238. Much has been written by scholars and activists that examine these complex issues in greater depth and sophistication than is appropriate for this Article. Accordingly, the discussion in this Article is meant primarily for instrumentalist purposes. See Helen Wells \& Louise Polders, Anti-Gay Hate Crimes in South Africa: Prevalence, Reporting Practices, and Experiences of the Police, 67 Agenda: Empowering Women for Gender Equity 20, 20 (2006). See generally Combating Violence Against LGBTI People in South Africa, Hum. RTs. First (Aug. 2, 2013), http://www.humanrightsfirst.org/2013/08/02/ combating-violence-against-lgbti-people-in-south-africa; Robyn Dixon, In South Africa's Black Townships, Being Gay Can Be Fatal, L.A. Times (May 27, 2011), http://articles.latimes.com/2011/may/27/world/la-fg-south-africa-gay-killings-20110528; Glynnis Underhill, People Are Dying as We Speak, Mail \& Guardian Online (May 6, 2011), http:/ /mg.co.za/article/2011-05-06-people-are-dying-as-we-speak. 


\section{Danger and Disfavor}

In a 2008 study of attitudes toward same-sex sexual activity, $83.6 \%$ of South Africans said it was always wrong. 239 Indeed, only $7.7 \%$ of South Africans reported believing that same-sex sexual activity was not wrong at all. ${ }^{240}$ These results are even more striking because they track attitudes toward activity unanimously declared constitutional by the Constitutional Court more than a decade earlier. Studies regularly show these kinds of disparities between popular attitudes and legal protections in South Africa. $^{241}$ Moreover, attitudes in South Africa seem to be improving slowly. A more recent 2013 study found that $61 \%$ of South Africans felt that society should not accept homosexuality. ${ }^{242}$ And while South Africa had dramatically higher favorable responses (32\%) than any other nation in Africa (the next highest was Kenya at 8\%), South Africa's rate of disfavor was significantly higher than any other nation with comparable legal protections. ${ }^{243}$

The disfavor with which gay and lesbian people (as well as bisexual and transgender people) are viewed results in frequent acts of overt discrimination and physical harm. As Justice Minister Radebe recently said, "Notwithstanding the comprehensive constitutional and legal framework and protection for LGBTI persons, we have sadly witnessed acts of discrimination and violent attacks being perpetrated against LGBTI persons." 244

Homophobic violence in South Africa has taken many forms but it has its most gruesome expression in the epidemic of so-called "corrective rape." Corrective rape is the practice of sexual assault primarily against lesbians or other gender non-conforming women and transgender persons, for the claimed purpose (or pretense) of "curing" them of their homosexuality. ${ }^{245}$ These crimes most frequently, though not exclusively, are perpetrated in townships against black lesbians. ${ }^{246}$ As a recent report baldly asserted, "rape is fast becoming the most widespread hate crime against lesbian women in townships across South Africa."247 While this category of hate crime is connected to the appalling prevalence of rape in South

239. Tom W. Smith, Cross-National Differences in Attitudes Towards Homosexuality, 31 GSS Cross-National Rep. 1, 17 (2011).

240. Id.

241. Id.

242. The Global Divide on Homosexuality: Greater Acceptance in More Secular and Affluent Countries, Pew Res. Ctr. (June 4, 2013), www.pewglobal.org/2013/06/04/theglobal-divide-on-homosexuality.

243. Id.

244. SAPA, Radebe Launches LGBTI Violence Programme, IOL News (Apr. 29, 2014), www.iol.co.za/news/crime-courts/radebe-launches-lgbti-violence-programme-1.168156 3\#.VF_n6Mn4LC6.

245. We'll Show You You're a Woman: Violence and Discrimination Against Black Lesbians and Transgender Men in South Africa, Hum. RTs. WAтch (Dec. 5, 2011), https://www .hrw.org/report/2011/12/05/well-show-you-youre-woman/violence-and-discriminationagainst-black-lesbians-and.

246. See generally id.

247. Hate Crimes: The Rise of 'Corrective' Rape in South Africa, Action Aid (2009), www.rapeoutcry.co.za/home/wp-content/uploads/2012/09/ActionAid-Corrective-Rape .pdf. 
Africa, the roots of this specific form of violence lie in both sexism and hatred of LGBT persons. ${ }^{248}$ Moreover, while the rape statistics are unlikely to reflect the full scope of the problem (as with both sexual assault and anti-gay hate crimes generally), there are estimates of up to ten reported corrective rapes a week. ${ }^{249}$

There are critical concerns about corrective rape that extend beyond the acts of violence to doubts about the state's response: Do police sufficiently investigate the crimes? Do state prosecutors diligently pursue the perpetrators? Do local authorities show adequate concern? Does public opinion sufficiently condemn these acts? Fundamentally, are the state and the public complicit in this on-going epidemic of violence? At the intersection of "homophobia, sexism[,] and gender-motivated violence" there will be no easy solutions, but the on-going nature of the crisis demands a forceful and impactful response. 250

The government has acknowledged the many problems with discrimination, but has, thus far, been unable to solve them. The state has initiated a variety of legislative responses, including specialized legislation to address discrimination. Relevant laws include the Employment Equity Act, ${ }^{251}$ the Promotion of Equality and Prevention of Unfair Discrimination Act (the Equality Act), ${ }^{252}$ and other laws that touch on equality issues. ${ }^{253}$

248. See Lydia Smith, Corrective Rape: The Homophobic Fallout of Post-Apartheid South Africa, Telegraph (May 21, 2015), http://www.telegraph.co.uk/women/womens-life/ 11608361/Corrective-rape-The-homophobic-fallout-of-post-apartheid-South-Africa.html ("In a country strongly influenced by traditional cultures and religious groups, corrective rape is a reaction to protect the status quo ....").

249. Scott Long, A. Widney Brown \& Gail Cooper, Hum. Rts. Watch, More Than a Name: State-Sponsored Homophobia and Its Consequences in Southern Africa 193 (2003) ("In the absence of adequate statistical investigation, the evidence is anecdotal; the fear, though, is palpable"); see Lee Middleton, 'Corrective Rape': Fighting a South African Scourge, TIME (Mar. 8, 2011), http://content.time.com/time/world/article/0,8599 ,2057744,00.html ("South Africa should be a beacon of tolerance. Its constitution was the first in the world to outlaw discrimination based on sexual orientation .... But in the townships on the city's outskirts, another reality reigns. The rate of violence against women in South Africa is among the highest in the world.").

250. Roderick Brown, Corrective Rape in South Africa: A Continuing Plight Despite an International Human Rights Response, 18 ANN. Surv. InT'L \& Comp. L. 45, 47 (2012) (addressing what steps have already been taken and "what steps need to be taken to more effectively address the problem not only in South Africa, but also across the globe"); see Sekoetlane Jacob Phamodi, Hate Crimes: "Homophobic Rape," RaPe Outcry, www.rapeoutcry.co.za[domain DNE]/home/?page_id=177 (last visited Mar. 31, 2015). See generally Lorenzo Di Silvio, Correcting Corrective Rape: Carmichele and Developing South Africa's Affirmative Obligations To Prevent Violence Against Women, 99 GEo. L.J. $1470,1474-75$ (2011) (suggesting what South Africa's affirmative obligations to prevent corrective rape might look like).

251. See generally Employment Equity Act 55 of 1998 (S. Afr.) ("[To] eliminate unfair discrimination in employment [and] redress the effects of [past employment] discrimination.").

252. See generally Promotion of Equality and Prevention of Unfair Discrimination Act 4 of 2000 (S. Afr.) (prohibiting unfair discrimination by government, private organizations, and individuals through legislation, measures, and remedies); DeP'T OF JUSTICE and Constitutional Dev., Stand and Defend your Right to Equality (2011) (explaining terms and provisions of the Promotion of Equality and Prevention of Unfair Discrimination Act). 
These laws attempt to translate the constitutional discrimination prohibitions into statutory law. Parliament has also established specialized Equality Courts to address discrimination by private parties. But the discrimination and the violence continue:

In spite of this enabling legal environment, the lived reality for many LGBTI persons is quite a different story. On the most extreme end of a wide spectrum of discriminatory experiences, there are frequent reports of extreme violence inflicted on young, black, lesbian women in the form of so-called "corrective" rape, often ending in murder. Gay men and transgender persons are also often targets of physical violence, and labour discrimination and exposure to derogatory and threatening speech is also common. Finally, deprioritisation, marginalisation, exclusion[,] and targeted victimisation by those public institutions intended to provide services and protection are everyday realities for LGBTI persons in many communities, leading to a lack of resources when crimes are committed and resulting in victims' fear to even report crimes. ${ }^{254}$

Consequentially, many gays and lesbians continue to have a particular and realistic fear of discriminatory treatment and homophobic violence, regardless of the constitutional and statutory protections.

\section{Social Change and the Courts}

It is no great revelation that even the much-praised South African courts have proven insufficient to eradicate discrimination based on sexual orientation. Courts cannot achieve a socially just society on their own, neither generally nor in the limited context of gay and lesbian equality. Progressive constitutional rights, a sympathetic court, and willing plaintiffs are not enough. This is true despite the fact that the gay rights litigation strategy of the last two decades has been, from an objective and relative perspective, exceedingly successful at securing pro-gay rulings and transitioning lofty constitutional promises into concrete legal rules.

Expectations of judicial impacts on social transformation should be modest in scope and appropriately tailored. Regrettably, it is reasonable to expect only limited outcomes from courts, not full-scale change. ${ }^{255}$ This is particularly true in nations like South Africa, where both the Court's and the Constitution's views are so divergent from popular opinion. Substantive change in social attitudes must come from extra-judicial efforts-particularly from civil society and cause-based organizing. ${ }^{256}$ Ideally, this is accompanied by appropriate support from governmental entities.

253. See, e.g., Alteration of Sex Description and Sex Status Bill of 2003, Bill 37B (S. Afr.) (allowing legal change of sex identification under limited circumstances).

254. See generally Dep't of Justice and Constitutional Dev., National Intervention Strategy for Lesbian, Gay, Bisexual, Transgender and Intersex (LGBTI) Sector (2014), www.justice.gov.za/vg/lgbti/2014-LGBTI-Strategy.pdf.

255. See Gerald N. Rosenberg, The Hollow Hope: Can Courts Bring About Social CHANGE? 3 (1991) (arguing that judicial capacity for social change is limited). See generally Leveraging the Law: Using the Courts to Achieve Social Change (David A. Schultz ed., 1998) (discussing a variety of critical responses to the Hollow Hope thesis).

256. See RosenberG, supra note 255, at 7-8. 
The South African Constitutional Court's contributions were assuredly groundbreaking and legally transformative, but the Court has been an insufficient instrument for the realization of full, substantive equality for gays and lesbians in South Africa. Nevertheless, the final part of this Article identifies several significant and affirmative comparative lessons drawn from how the Court has crafted, interpreted, and enforced its progressive, gay-rights inclusive, and rights-oriented Constitution.

\section{Lessons from the South African Experience}

Careful examination of the drafting history, Constitutional Court adjudication, and the practical insufficiencies of the South African Constitution's inclusion of sexual orientation protections highlights three categories of lessons drawn from the last two decades of constitutional rights in South Africa. These lessons include an encouraging insight about novel and progressive elements in the drafting of modern constitutions, some modest claims about the capacity of courts to combat inequality based on sexual orientation, and a hopeful affirmation of the value of even unrealized constitutional aspirations for the fields of comparative constitutionalism and gay and lesbian equality.

\section{A. Lessons for Progressive Constitutional Drafting}

Rather than being a cautionary tale about progressive constitutiondrafting hubris, two decades of constitutional adjudication in South Africa demonstrate the real, if modest, rewards of bold constitutionalism. Following apartheid, the capacious vision of substantive equality in enumerated civil, political, and socio-economic rights was joined with a broadly empowered and respected institution, the Constitutional Court. The pairing of effusive rights protections with a capstone court composed of justices aligned with the values of the new transformative Constitution created an opportunity for considerable rights adjudication in just twenty years. This achievement started with the enumeration of these rights in the Constitution

If end-of-the-century human rights scholars had written a "best practices" manual for constitution drafters, the collection of rights and the mechanisms for enforcement of those rights would look very much like the South African Bill of Rights in the 1996 Constitution. Of course, that is no coincidence. The process of drafting the South African Constitution was "a deliberate attempt to have a fundamental instrument of government that embraced basic human rights." 257 As its Preamble states, one of the Constitution's core purposes was to "establish a society based on democratic values, social justice[,] and fundamental human rights." 258

257. Jonathan Faull, Ruth Bader Ginsburg Knows Her Constitutions, Africa Is A CounTRY (Feb. 16, 2012), www.africasacountry.com/ruthbaderginsburg/ (quoting U.S. Supreme Court Justice Ruth Bader Ginsberg).

258. S. Afr. Const., 1996, pmbl. 
One of the abiding lessons from the South African experiment in progressive constitutionalism is that constitutional drafting need not fit within traditional or proven patterns. Novelty in constitution making is not a per se flaw. The South African Constitution included relatively exceptional rights (for example, enforceable social welfare and sustainable environmental rights) with broad applicability (including prohibitions on private discrimination and expanded non-discrimination categories like sexual orientation) and permitted generous enforcement through its permissive standing and remedial provisions. ${ }^{259}$ For many commenters, this was promising too much. ${ }^{260}$ It seemed a recipe for popular disappointment, court delegitimation, or state failure. But the last twenty years of progressive constitutional adjudication in South Africa belie that expectation.

Of course, rights in a constitutional document are not enough; an empowered judiciary aligned with those constitutional values is, similarly, a necessary but insufficient element. "Bold Constitutions require bold judges." 261 The first generation of South African justices had significant prior exposure to human rights issues, having seen their denial first hand by the time of their 1994 appointment by President Mandela. ${ }^{262}$ Having participated in the struggle against apartheid, they saw transformative rights adjudication as a core purpose of the Constitutional Court. As former Chief Justice Chaskalson described it, "Under our Constitution the normative value system and the goal of transformation, are intertwined."263

The expansive progressive elements of the Constitution have worked, in large part, because the drafters and the justices shared an affirmative constitutional purpose: facilitating South Africa's transformation from the apartheid state to a multi-racial democracy. The Constitution "demands [of judges] . . . a legal order be established that gives substance to its founding values-democracy, dignity, equality[,] and freedom . . ."264 This approach envisions South Africa as a reformed country, a "human rights state" intent on transforming itself into an example to other nations. ${ }^{265}$

The Constitutional Court evidently sees itself as the primary guardian

259. See, e.g., Eric C. Christiansen, Transformative Constitutionalism in South Africa: Creative Uses of Constitutional Court Authority to Advance Substantive Justice, $13 \mathrm{~J}$. GENDER, RACE \& Just. 575, 576 (2010) [hereinafter Christiansen, Transformative Constitutionalism].

260. See, e.g., Dennis Davis, The Case Against Inclusion of Socio-Economic Demands in a Bill of Rights Except as Directive Principles, 8 S. Afr. J. Hum. Rts. 475, 488-89 (1992).

261. See Letter from Albie Sachs, supra note 43, at 224.

262. Many of the justices, especially the ANC members, had joined foreign law faculties, human rights organizations, and NGOs, or had participated in meetings or international conferences related to apartheid and human rights. See Judges, Const. C. . S. Afr., http://www.constitutionalcourt.org.za/site/judges/formerjudges.htm (last visited Sept. 23, 2016) (providing biographies of current and former justices).

263. Arthur Chaskalson, C.J., Const. Ct. of S. Afr., Justice Chaskalson's Farewell Speech (June 2, 2005), http://www.constitutionalcourt.org.za/site/thecourt/farewell .htm.

264. Id.

265. See S. Afr. Const., 1996, pmbl. ("We . . adopt this Constitution . . . to . . . establish a society based on ... fundamental human rights."). 
and expositor of the Constitution. ${ }^{266}$ It has been the "the key institution of [South African] constitutional democracy." 267 From the time it was founded and given the task of certifying the Constitution to its ongoing charge of monitoring the lower judiciary and assessing the constitutionality of all government actions, the Court has been at the center of South Africa's transition. Even twenty years later, and after the death or retirement of all of its original members, the Court's review of current controversies still encourages popular and legislative dialogue about the Constitution's commitment to progressive goals and it further advances its reformist values. It reminds all South Africans that the Constitution's historic promises remain relevant to present problems. This reinforces the ongoing role of the Constitution's values in present-day society. In fact, reinforcing the values of the founding generation through their written judgments remains a particularly important role of Constitutional Court Justices, even two decades after the court's initial decisions.

For example, with regard to progressive rights of equality for gays and lesbians, which many people oppose on religious or other grounds, the Court plays a critical role, reaffirming the commitments South Africans made in the Constitution-even if those commitments are personally disfavored. Its legitimacy and authority allows the Court to assert expansive equality as a core constitutional value in a manner that re-connects it to its origins in non-racialism and the struggle against apartheid.

In part, the Constitutional Court's successes have resulted from its capacity to maintain and reinvigorate South Africa's "constitutional moment," the period of expectancy and generosity at the end of apartheid and the start of democratic constitutionalism. The Court's frequent references to post-apartheid transformation and constitutional values support its progressive and expansive rulings, reminding South Africans of a more optimistic moment in time when the commitments were initially made.

Subject to necessary caveats related to the limited power of the judiciary to effect social change, the South African Constitutional Court has inaugurated an impressive jurisprudence-substantive equality expressed through robust anti-discrimination and the promotion of human dignity, social welfare, and democratic participation-in service of the constitutional purpose of transforming South Africa. One obvious lesson of the last twenty years is that progressive textual rights can advance social justice and constitutional transformation, to a modest but beneficial extent, when entrusted to an empowered and values-aligned judiciary.

266. History of the Court, Const. CT. S. AFr., www.constitutionalcourt.org.za/site/ home.htm (last visited Sept. 23, 2016); see also Const. Cт. S. Afr., www.constitutionalcourt.org.za/site/home.htm (last visited Sept. 23, 2016) ("[T] he 11 judges stand guard over the Constitution and protect everyone's human rights."); Former Judges, Const. Ст. S. Afr., http://www.constitutionalcourt.org.za/site/judges/formerjudges.htm (last visited Sept. 24, 2016).

267. History of the Court, supra note 266. 


\section{B. Lessons for Advancement of Constitutional Equality}

The South African Constitutional Court has employed several different strategies for maximizing equality, including gay and lesbian equality. As discussed below, the justices use their reasoning and judgments to guide official action by the other branches of government; they strengthen their own authority by leveraging the legitimacy of the elected branches, the ANC, and the anti-apartheid struggle; and they empower future plaintiffs through their expansive assurances of broad-based equality under the Constitution.

\section{Guiding Official State Action}

The Court's gay and lesbian rights decisions have intentionally and proactively pressured the executive and legislative branches to act consistently with their constitutional duties. In and of itself, this is unremarkable; courts always have the role of executing this guidance function. The role of legal precedent has always been to inform state actors of the future likelihood of particular legal results for relatively similar parties in relatively similar situations. But the South African Constitutional Court has gone further.

The Court has encouraged the political branches to take specific action that would advance substantive equality, occasionally chiding them to do so. The most obvious examples are the cases that preceded the marriage equality decision in Fourie. The Court rebuked Parliament for its failure to pass "comprehensive legislation" related to gay and lesbian family law and marriage. As multiple cases highlighted this deficiency between 1999 and 2003, the Court was no longer content with implying that Parliament should act. In the last gay rights case before Fourie, the Court pointedly declared that "[i]t is not appropriate for courts to determine [details of laws implementing marriage equality] .... Those are matters for the legislature . . .."268 When Parliament failed to act in a timely and concrete manner, the Court focused the legislative task and required Parliament's action by ordering it to act on marriage equality or to have a judicial solution imposed on the nation within one year. ${ }^{269}$ The Court's calculated use of the text, history, and purpose of South Africa's transformative Constitution ensured legislative cooperation in implementing gay and lesbian legal equality.

Moreover, the Court's decision to require a legislative remedy could be understood to show that Parliament may not escape its constitutional responsibilities through judicial resolution. Not all forms of guidance are as direct as the Court's approach in Fourie. Perhaps this is because the other government branches are not typically as obstinate. However, when the other branches respond in an early and appropriate manner, by passing affirmative legislation or altering government practices, the changes

268. J and B v. Dir. Gen., Dep't of Home Affairs \& Others 2003 (5) SA 621 (CC) at para. 26 (S. Afr.).

269. Minister of Home Affairs v. Fourie 2005 (1) SA 524 (CC) at 98 para. 158 (S. Afr.). 
never appear in the case reports of the Constitutional Court. Hence, the overall effectiveness of this guidance function may be unknowable, even if its importance is inarguable. This is particularly true in a jurisprudential area of ample and consistent judicial action, like the field of gay and lesbian equality.

\section{Leveraging Legitimacy}

A second strategy of the Court focuses on maximizing the influence of its decisions by bolstering its status and relative acceptance. Stable constitutionalism requires institutional and popular legitimacy for court judgments. This is particularly the case when a constitution seeks to "[h]eal the divisions of the past and establish a society based on democratic values, social justice[,] and fundamental human rights." 270 Transformative constitutionalism requires the Court to maximize its legitimacy whenever possible. ${ }^{271}$ At the most general level, the Court's consistent use of plain language rather than specialist legal terminology promotes legitimacy by making the Court's reasoning more accessible. ${ }^{272}$ Similarly, the Court routinely issues very brief summaries of important cases, targeted at the media. These summaries support clear communication of the reasoning and result of the Court's judgment, with the aim of enhancing understanding and support of its decisions. ${ }^{273}$

Fourie again provides a helpful example. ${ }^{274}$ The Court's carefully circumscribed marriage equality order to Parliament ${ }^{275}$ leveraged the democratic authority of the National Assembly generally and the popularity of the ANC specifically to bolster the desired result. ${ }^{276}$ The intended result was electorally legitimized because it was democratically legislated with support from the politically and culturally dominant ANC. The Court, Parliament, and the ANC seemed aware of this motivation for assigning this task to Parliament rather than merely remedying the injustice through judicial fiat. ${ }^{277}$

270. S. Afr. Const., 1996, pmbl.

271. Christiansen, Transformative Constitutionalism, supra note 259.

272. Frans Viljoen, Baring The Nation's Soul Through Plain Language, 46 Clarity 15, 15 (2001).

273. See, e.g., Satchwell v. The President and Another: Explanatory Note, S. Afr. Legal INFO. INST., Www.saflii.org/za/cases/ZACC/2002/18media.pdf (last visited Oct. 6, 2016); DuToit and Another v. The Minister For Welfare and Population Development and Others: Explanatory Note, S. Afr. Legal Info. InST., www.saflii.org/za/cases/ZACC/ 2002/20media.pdf (last visited Oct. 6, 2016).

274. Fourie 2005 (1) SA 524 (CC) at 91-94 paras. 148-50 (S. Afr.).

275. Id. at 100-01 para. 161 .

276. Id. at 100 para. 160 .

277. See, e.g., Home Affairs Portfolio Comm., Civil Union Bill, Film \& Publications \& Immigration Amendment Bills: Briefing (Sept. 13, 2006), Parliamentary Monitoring Group, www.pmg.org.za/minutes/20060912-civil-union-bill-films-publications-immigration-amendment-bills-briefing-department (discussing "the Fourie judgment [sic] which had placed the Executive, Parliament as well as [the Legal Advisor's] office under considerable pressure to amend the legislation or to alternatively introduce separate legislation .... . [T]hey also very carefully studied all other Constitutional Court cases and other relevant jurisprudence on the topic of same sex marriages."). 
The marriage equality legislation that eventually passed 278 could claim greater political legitimacy, and the process of its passage prompted discussion of gay rights issues popularly. The Court had used its openended remedial power to advance substantive equality through a process that bolstered the socio-political elements of equality. In this way, the Court was able to reinforce the constitutional value of equality in a more productive and potentially enduring manner than if it had merely invalidated the law or "read in" language to alter existing marriage laws. ${ }^{279}$

\section{Inspiring Future Claims}

The Court's gay rights jurisprudence can inform future anti-discrimination and affirmative protection claims in at least two substantive ways. First, it can provide a generous model for additional rights claims related to sexual orientation and gender identity, extending the legal protections for gays and lesbians to additional segments of the LGBTI community. And secondly, future advocates may seek court orders of a more affirmative nature, requiring the government to satisfy its affirmative duties to "respect, protect, promote[,] and fulfill" 280 the constitutional promise of equality.

It is unfortunate, however, that the Court has not spoken more substantively about the meaning and constitutional significance of sexual orientation outside the application to gays and lesbians. Additionally, it is regrettable that the Court has not yet had occasion to significantly address discrimination related to gender identity-especially because gender is a distinctly protected category (in addition to sex) in the Equality Clause. ${ }^{281}$

The Court did adopt a working definition of sexual orientation in the NCGLE Sodomy case: "[S]exual orientation is defined by reference to erotic attraction: in the case of heterosexuals, to members of the opposite sex; in the case of gays and lesbians, to members of the same sex." 282 Moreover, the Court described the term "sexual orientation" in the Constitution as "linguistically and textually fully capable of bearing" a "generous interpretation." 283 The Court said that protections apply "equally to the orientation of persons who are bi-sexual, or transsexual and it also applies to the

278. See generally Civil Union Act 17 of 2006 (S. Afr.).

279. This was, unsurprisingly, the Court's back-up plan. Fourie 2005 (1) SA 524 (CC) at 100-01 para. 161 (S. Afr.) ("Should Parliament not correct the defects within this period, Section 30(1) of the Marriage Act 25 of 1961 will forthwith be read as including the words 'or spouse' after the words 'or husband' as they appear in the marriage formula.").

280. S. Afr. Const., $1996 \S 7$.

281. Id. \& 9(3).

282. Nat'l Coal. for Gay and Lesbian Equal. v. Minister of Justice and Others 1999 (1) SA 6 (CC) at para. 20 (S. Afr.) [hereinafter NCGLE Sodomy] (citing the highly influential work, Cameron, Sexual Orientation and the Constitution, supra note 42). In a hopeful sign for future jurisprudence, Professor Cameron was appointed to the Constitutional Court in 2009. He was the first openly gay and HIV-positive justice. Chip Alfred, Bearing Witness, ARt \& Understanding MaG. (Dec. 10, 2011), http://www.aumag.org/2011/ 12/10/bearing-witness/.

283. NCGLE Sodomy 1999 (1) SA 6 (CC) at para. 21 (S. Afr.). 
orientation of persons who might on a single occasion only be erotically attracted to a member of their own sex."284 However, the Court has had little to say about the larger context of sexual orientation and gender identity since that case. Hopefully, when appropriate cases arrive, the Court's treatment of discrimination on the basis of homosexuality will model an expansive, dignity-focused approach to issues related to other forms of sexual orientation as well as to gender identity.

The Court's announcement of a constitutional requirement for "meaningful engagement" in the housing rights case Occupiers of 51 Olivia Road $v$. City of Johannesburg also has the potential to support substantive equality in future cases. ${ }^{285}$ In Olivia Road, the Court required the state to present evidence of good faith consultation with impacted individuals and concerned civil society organizations as a prerequisite to asserting that the state response was constitutionally adequate. ${ }^{286}$ Consequently, affected communities are significantly empowered to advocate for their own rights-particularly in the face of plausible claims of government inaction or indifference. In the context of gay and lesbian rights, this meaningful interaction requirement opens an additional avenue for organizing and engaging with the state related to the crisis of corrective rape (or other extant equality issues). If particularly affected communities-in this case township lesbians and others-are consulted, there is a far greater likelihood of improved outcomes, i.e., practicable strategies for greater safety and security, more effective prosecutions, and community educational programs to advance understanding and social acceptance

Such a result would likely lead to significantly improved outcomes for LGBT community stakeholders and might also increase popular involvement with government and educate the state bureaucracy about groundlevel discrimination issues. If the meaningful engagement requirement spreads from socio-economic rights to the field of equality or other categories of constitutional rights, the occurrence of good faith community consultation in one substantive area will raise expectations and facilitate improved outcomes in other areas.

Such a development is consistent with the transformational value of substantive equality in the South African Constitution. Equality in the modern South African constitutional tradition is not merely a prohibition on discriminatory government action-American style "negative liber-

284. Id. While the expansive references to issues not before the Court in the Sodomy case are important for later jurisprudential developments, there seems to be some conflation of gender identity issues ("transsexual") with sexual orientation issues ("bi-sexual" and earlier references in the case to heterosexuality and homosexuality). See id.

285. Occupiers of 51 Olivia Road, Berea Twp. and 197 Main St. Johannesburg v City of Johannesburg \& Others 2008 (3) SA 208 (CC) at 7-13 paras. 9, 18 (S. Afr.).

286. The Court not only asserts an expectation that public disclosure and consultation will actually occur but also issues orders with real consequences when it does not. Id. at 10-13 paras. 14-18 ("Engagement is a two-way process in which the City and those about to become homeless would talk to each other meaningfully in order to achieve certain objectives. There is no closed list of the objectives of engagement."). The Court not only asserted an expectation that public disclosure and consultation will actually occur, but also issued orders with real consequences when it does not. Id. 
ties."287 Rather, it is a constitutional goal with civil, political, and social welfare dimensions. As a consequence, judicial tools that advance any area of equality, like "meaningful engagement" to address socio-economic inequality, would appropriately be used to support more traditional dimensions of equality. When reviewed comparatively by other nations' courts, this process will offer a viable example of a creative use of judicial power to promote equality.

\section{Lessons for Comparative Equality and Constitutionalism}

The South African Constitution is a well-respected model for other countries and future constitutions. And, to the extent it guides content choices for future constitutional drafters and models rights adjudication for foreign courts, the Court's interpretation and application of the Constitution, amplifies its influence. Indeed, as a result of the Constitution's unique history, the document is viewed with great respect by members of the international community, and has been described by one commentator as one of the "newer, sexier[,] and more powerful operating systems in the constitutional marketplace."288 Even internationally known jurists have affirmed its particular strengths. United States Supreme Court Justice Ruth Bader Ginsberg recently encouraged Egypt to look to the model of the South African Bill of Rights as an exemplar for its new constitution. ${ }^{289}$ It shines a favorable light on South Africa as a whole; "South Africa's prohuman rights constitution, stable government, democratic institutions, independent judiciary, and strong economy mean it has great potential to become a global human rights leader."290

This makes the constitutional provisions (and their interpretation) even more important in comparative context; the South African Constitution is worthy of consideration as an example for burgeoning democracies. Since 1994, it has been noted by other countries that South Africa chose to include express protections based on sexual orientation in its Constitution. ${ }^{291}$ This decision by the drafters has had an impact far beyond the

287. In one famous iteration of this notion, American Judge Richard Posner stated:

$[\mathrm{T}]$ he Constitution is a charter of negative rather than positive liberties .... The men who wrote the Bill of Rights were not concerned that government might do too little for the people but that it might do too much to them. The Fourteenth Amendment, adopted in 1868 at the height of laissez-faire thinking, sought to protect Americans from oppression by state government, not to secure them basic governmental services.

Jackson v. Jolliet, 715 F.2d 1200, 1203 (1983) (citing Harris v. McRae, 448 U.S. 297, 322 (1980) ("The guarantee of equal protection under the Fifth Amendment is not a source of substantive rights or liberties, but rather a right to be free from invidious discrimination in statutory classifications and other governmental activity.")).

288. Adam Liptak, 'We the People' Loses Appeal with People Around the World, N.Y. Times, Feb. 7, 2012, at Al, www.nytimes.com/2012/02/07/us/we-the-people-losesappeal-with-people-around-the-world.html.

289. Id.

290. World Report 2011: South Africa Annual Country Report, Hum. Rts. Watch, www .hrw.org/world-report-2011/south-africa (last visited Mar. 31, 2015).

291. See, e.g., Jill Cottrell \& Yash Ghai, Constitution Making in Fiji: Context and Process, in The Role of Constitution-Building Process in Democratization 1, 16 (2004), 
country's borders. The effective creation of a new, default list of categories for Equality Clause protection, which includes sexual orientation, does not ensure that future nations will adopt the protections but it may fundamentally alter the presumptive text of equality provisions as future constitutions are drafted. The impact of the Constitution's expansive rights protections is magnified because the Constitutional Court has applied the provision extensively.

The Constitutional Court's jurisprudence is also a model for other nations. Its international and comparative influence highlights the significance of the Court's affirmative gay rights jurisprudence. Because the South African Constitutional Court has interpreted the first sexual orientation protections to appear in a national constitution, its treatment of inclusive equality provisions is also inescapably important. Was it to be a full, substantive right worthy of adjudication and protection or merely window dressing with no legal impact?292 The Court's unanimous, affirmative rulings advancing each of the adjudicated elements of gay and lesbian equality have answered that question decisively. The South African Constitutional Court, drawing on a greatly respected constitution and considering international and comparative law in its decisions, robustly protects the equality of gays and lesbians and affirms their fundamental equality and human dignity.

Because the judgments come from the South African Constitutional Court, they are more likely to be noticed by other nations' courts and they may more easily join the comparative law conversation about human rights adjudication. The expansive case law prohibiting discrimination based on sexual orientation is of singular importance in comparative context-particularly at this time when a significant number of courts are adjudicating and, with legislators, debating issues of gay and lesbian equality. The South African Court has always seen itself as part of a global conversation about constitutional values and constitutionalism. When the Court speaks about equality and gay rights in its cases, it not only speaks to an attentive international audience but also from a unique depth of experience.

http://www.constitutionnet.org/files/cbp_fiji.pdf ("[A]pparently, in possession of the South African constitution, they managed to sneak in an idea or two of their own. It seems that the inclusion of sexual orientation as a prohibited ground of discrimination comes from the drafters; certainly it is not in the [report of the original constitutional negotiating body].").

292. The lesson of Fijian constitutionalism is relevant here as well. The short-lived Fijian Constitution of 1997 (the second constitution in the world to include express protections based on sexual orientation) and the most recent iteration, the Fijian Constitution of 2013, both included sexual orientation (and gender identity) in their equality clauses but made special exceptions related to marriage, adoption, and other areas of family law. See Const. OF the Republic of Fij \& 26. See generally Fiji: Revise Draft Constitution to Protect Rights, Hum. RTs. Watch (Sept. 4, 2013), www.hrw.org/news/2013/ 09/04/fiji-revise-draft-constitution-protect-rights. 


\section{Conclusion}

It is appropriate and valuable to critically examine the significance and achievements of the constitution that ended South African apartheid twenty years ago. Among the successes of the South African Constitution is its novel, progressive inclusion of equality protections for gays and lesbians. The prohibition of discrimination based on sexual orientation was particularly important because it occurred in this historic human rights constitution. Moreover, the ensuing gay rights jurisprudence of the South African Constitutional Court is the most protective in the world. The Constitutional Court's opinions include express affirmations of the dignity and equality of gays and lesbians in an unbroken series of unanimous, progay decisions that form a substantial core of the overall equality jurisprudence of the Court. In particular, three defining characteristics facilitated adjudicatory success related to gay and lesbian rights: a protective constitutional text, a progressive Constitutional Court, and an effective litigation strategy.

Nevertheless, South African gays and lesbians are currently facing the daunting challenge of leveraging legal victories into broader, societal equality. Twenty years after the prohibition of sexual orientation discrimination in the Equality Clause of the South African Constitution, the protections' practical effects have been woefully inadequate to achieve the safety and social equality of gays and lesbians in South Africa. In sharp contrast to the expansive textual protections and progressive jurisprudence, the lived reality of South Africans gays and lesbians, particularly in poorer communities, is typified by condemnation, discrimination and homophobic violence. Hence, the Equality Clause protections are a symbol of both the progressive human rights reach of the post-apartheid Constitution and the gulf between textual promises and reality.

Moreover, there are risks ahead that highlight the critical need for broader public support. Judicial action is relatively insecure; it is subject to legislative revision, constitutional amendment, and executive inaction. Change through judicial rulings without popular affirmation may be fleeting, ineffective, or merely symbolic. And, more than at any other point in the last two decades, there is uncertainty about the road ahead for South Africa. With open questions of party discipline and frequent allegations of abuse of political power, the stakes are much higher for the extra-legal, social equality side of the struggle for gay and lesbian equality in South Africa. Without changes in public opinion, the steady legal gains of the last two decades are threatened by the potential for constitutional amendment (relatively easy under the current make-up of Parliament) ${ }^{293}$ or a

293. The Constitution can be amended relatively easily by the two houses of Parliament. S. AFr. Const., 1996 § 74(2) ("[The Bill of Rights] may be amended by a Bill passed by (a) the National Assembly, with a supporting vote of at least two thirds of its members; and (b) the National Council of Provinces, with a supporting vote of at least six provinces...."). Following the 2014 elections, the ANC held 249 of 400 seats (62.15\%) of the National Assembly. 2014 National and Provincial Election Results, ELECtoral Comm. S. Afr., http://www.elections.org.za/resultsnpe2014/ (last visited Mar. 31, 
populist, conservative turn by a weakened ANC seeking to maintain political dominance.

In this Article, I have examined the Constitution's drafting history, the Constitutional Court's gay rights jurisprudence, and the practical insufficiencies of the Constitution's inclusion of sexual orientation-based protections. I have done so in order to highlight three insights about the last two decades of constitutional rights in South Africa: an encouraging insight about novel and progressive elements in the drafting of modern constitutions, several modest claims about the capacity for courts to combat inequality based on sexual orientation despite the limitations of purely legal victories, and a hopeful affirmation of the value of even unrealized constitutional aspirations for the fields of comparative constitutionalism and gay and lesbian equality.

The inclusion of sexual orientation protections in the constitution that ended apartheid in South Africa stands as a figurative marker at the beginning of the modern, constitutional era for equality for gay men and lesbians. Its legal significance is singular and substantial. But it can only support social equality, not achieve it. The legal protections themselves require a powerful Court, a stable political sphere, and durable, widespread trust in South Africa's transformative constitutional values.

2015). The ANC also held sixty of ninety seats on the National Council of Provinces (with a majority of seats in seven of the nine provinces). Members of Parliament, PARLIAMENTARY Monitoring Group, https://pmg.org.za/members/ (last visited Mar. 31, 2015). 
